\title{
Remaking History: The Shu and Wu Perspectives in the Three Kingdoms Period
}

\section{Citation}

Xiaofei Tian. 2016. "Remaking History: The Shu and Wu Perspectives in the Three

Kingdoms Period." Journal of the American Oriental Society 136 (4): 705. doi:10.7817/ jameroriesoci.136.4.0705.

\section{Published Version}

doi:10.7817/jameroriesoci.136.4.0705

\section{Permanent link}

http://nrs.harvard.edu/urn-3:HUL.InstRepos:34390354

\section{Terms of Use}

This article was downloaded from Harvard University's DASH repository, and is made available under the terms and conditions applicable to Other Posted Material, as set forth at http:// nrs.harvard.edu/urn-3:HUL.InstRepos:dash.current.terms-of-use\#LAA

\section{Share Your Story}

The Harvard community has made this article openly available.

Please share how this access benefits you. Submit a story.

\section{Accessibility}




\title{
Remaking History: The Shu and Wu Perspectives in the Three Kingdoms Period
}

\author{
XIAOFEI TIAN \\ HARVARD UNIVERSITY
}

\begin{abstract}
Of the three powers-Wei, Shu, and $\mathrm{Wu}$ - that divided China for the better part of the third century, Wei has received the most attention in the standard literary historical accounts. In a typical book of Chinese literary history in any language, little, if anything, is said about $\mathrm{Wu}$ and Shu. This article argues that the consideration of the literary production of Shu and $\mathrm{Wu}$ is crucial to a fuller picture of the cultural dynamics of the Three Kingdoms period. The three states competed with one another for the claim to political legitimacy and cultural supremacy, and $\mathrm{Wu}$ in particular was in a position to contend with Wei in its cultural undertakings, notably in the areas of history writing and ritual music. This article begins with an overview of Shu and Wu literary production, and moves on to a more detailed discussion of Wu's cultural projects, both of which were intended to assert Wu's legitimacy and cultural power vis-à-vis Wei and Shu's claims to cultural and political orthodoxy. Ultimately, this article implicitly asks the question of how to write literary history when there is scant material from the period under question, and suggests that we perform textual excavations and make use of what we have to try and reconstruct, as best as we can, what once was. A good literary history of the Chinese medieval period, the age of manuscript culture and that of heavy textual losses and transfigurations, should be written with the awareness of the incomplete and imperfect nature of the data we do have, and incorporate the phenomenon of textual losses and transfigurations as well as some reflections on the underlying reasons into its narrative and critical inquiry.
\end{abstract}

\section{INTRODUCTION: THE LOST LITERARY HISTORY}

A gap in standard Chinese literary history, so large that it becomes imperceptible, glares at us. Of the three powers-Wei 魏, Shu 蜀, and Wu 吳—that divided China for the better part of the third century, Wei has received the most attention in standard literary historical accounts; little, if anything, is said about the literary production of $\mathrm{Wu}$ and Shu during the Three Kingdoms period (220-65). Opening any typical work of Chinese literary history, we find that the account of the third century is dominated by a linear narrative organized around the literary output of the three political eras, that is to say, the Jian'an 建安 era (196-220) of the Eastern Han dynasty (25-220), the Zhengshi 正始 era (240-49) of the Wei dynasty (220-65), and the Taikang 太康 era (280-89) of the Western Jin dynasty (265-316). The narrative is further punctuated by a few stellar clusters, namely Wei's ruling family, the house of Cao 曹; the “Seven Masters of the Jian'an Era” (Jian'an qizi 建安七子); and the “Seven Worthies of the Bamboo Grove" (zhulin qixian 竹林七賢), in particular its two literary luminaries, Ruan Ji 阮 籍 (210-263) and Xi Kang 森康 (223-262).

I wish to thank Antje Richter and the two anonymous readers for their critical feedback and helpful suggestions for improving the article. Any remaining fault is clearly my own. 
This story is so familiar to any student of classical Chinese literature that it is largely taken for granted. The Three Kingdoms period is a popular topic of poetry, fiction, and drama in later times, with Shu and Wu playing central roles in the saga; however, the literary works of these two states themselves have curiously slipped into oblivion. A recent volume of Chinese literary history summarizes the Three Kingdoms literature in the following characteristic statement: "The state whose literature flourished the most was Wei. The literary texts of the other two states that have been preserved and transmitted are very few and have no distinctive characteristics." ${ }^{1}$ Literature did flourish in the Cao-Wei court, but Shu, despite being the smallest and weakest of the three states, was not devoid of scholarly, and to a less significant extent, literary activities. As for $\mathrm{Wu}$, it is a different story altogether: judging from the list of literary collections in the "Bibliography" section of the early seventh-century Sui $s h u$ 隋書 (History of the Sui), and judging from records in earlier historical sources, the Wu court boasted an impressive array of scholars and writers. The perceived lack of "distinctive characteristics" is a debatable issue, as the Wu writings certainly have a strong "local" character that is difficult to ignore.

The phenomenon that so few writings have been transmitted from the other two states, especially from the textually productive $\mathrm{Wu}$, deserves some reflection. In fact, such textual loss itself should constitute part of the literary historical narrative. Ultimately, two intertwining factors are at work here. First, the literary judgment, made by men of letters in the fifth and sixth century, largely bypassed $\mathrm{Wu}$ and Shu and looked to the northern state of the Central Plains - the Wei-as representing the orthodox lineage in literature. Since the Southern Dynasties (420-579) were heirs of the Western Jin, the dynasty that replaced Wei and unified China, their literary view was colored by their political view regarding legitimacy and orthodoxy. In the influential sixth-century anthology Wen xuan 文選, no poem or poetic exposition ( $f u$ 賦) by any Wu or Shu writer is anthologized, despite the fact that a large number of literary collections by Wu writers were still extant when Wen xuan was being compiled. ${ }^{2}$ The preference for the Cao-Wei at the expense of Shu and especially Wu represents the culmination of a long process of canonizing the Jian'an/Cao-Wei writers, which can be traced back to at least the early fifth century. ${ }^{3}$ Second, the canonization of the Jian'an/CaoWei community was to a large degree responsible for the loss of most of the textual remains from Shu and $\mathrm{Wu}$, and the textual dearth subsequently obscures modern scholars' view of the actual state of literary production in the third century. The extant writings from $\mathrm{Wu}$ only

1. Zhongguo wenxue shi xinzhu 中國文學史新著, comp. Zhang Peiheng 章培恆 and Luo Yuming 駱玉明 (Shanghai: Fudan daxue chubanshe, 2011), 282.

2. While there is a plethora of writings from the Wei in the remaining sections of the Wen xuan, only two compositions by Shu and Wu writers from the Three Kingdoms period are included. These are Zhuge Liang's 諸葛亮 (181-234) “Memorial to the Throne on Starting a Military Campaign” (Chushi biao 出師表) and Wei Zhao's 韋 昭 (204-273; changed to Wei Yao 韋曜 to avoid Jin taboo) “Disquisition on Liubo and Chess Games” (Boyi lun 博娈論). Xiao Tong 蕭統 (501-531), comp. Wen xuan (Shanghai: Shanghai guji chubanshe, 1986), 37.1671-74, 52.2283-86. Wen xuan also includes several pieces of writing denouncing Wu and Shu, such as Chen Lin's 陳琳 (d. 217) “Proclamation against the Wu Generals and Soldiers" (Xi Wu jiangxiao buqu wen 檄吳將校部曲文), Zhong Hui's 鍾會 (225-264) “Proclamation against Shu” (Xi shu wen 檄蜀文), and Ruan Yu's 阮㻦 (d. 212) “Letter to Sun Quan [Wu's ruler, 182-252] on Behalf of Lord Cao [Cao 操, 155-220]” 為曹公作書與孫權 (Wei Cao gong zuoshu yu Sun Quan). In contrast, we see no counterpart of such denunciation from Shu and Wu, even though Shu and Wu were quite capable of their own political propaganda. Wen xuan 44.1976-90, 42.1887-93.

3. For a preliminary discussion of the construction of the literary era “Jian'an," see Tian Xiaofei 田曉菲, “Yanyin yu huiyi: Chongxin sikao Jian’an” 宴飲與回憶: 重新思考建安, Zhongguo wenxue xuebao 中國文學學報 2010.1: 22-34. For the efforts of Southern Dynasties men of letters to organize, select, and canonize "Han" poetry, see Stephen Owen, The Making of Early Chinese Classical Poetry, Chap. 1, “'Han' Poetry and the Southern Dynasties" (Cambridge, Mass.: Harvard Asia Center Press, 2006), 23-72. 
form a tiny little tip of what once had been a considerable corpus of writing by Wu writers, who had authored commentaries on the classics, book-length "masters works," Wu history, and, last but not least, poetry and poetic exposition, the proper stuff of belletristic literature.

The emphasis on Wei culture and thought in modern scholarship, as J. Michael Farmer has observed, "mirrors and perpetuates traditional biases against southern culture and results in a distorted and incomplete picture of intellectual life in early medieval China." 4 Nevertheless, in many ways we cannot properly assess the cultural and literary production of the Wei without considering Shu and Wu. Cao Pi 曹丕 (187-226, r. 220-226), Wei's founding emperor, felt compelled to represent himself as a man of taste in literary and cultural matters, and his urge was in no small measure due to the political need to best his rivals. ${ }^{5}$ The three kingdoms competed with one another for the claim to political legitimacy and cultural supremacy.

At the most obvious level, the battle of wits is constantly present during diplomatic missions. Many anecdotes tell of emissaries' eloquence in defending the honor of their home state. For instance, Zhao Zi 趙咨 (fl. early third century), well known for his oratorical skills, gave apt replies to Cao Pi's pointed questions, such as, "What sort of ruler is the King of Wu? Is His Grace well-versed in learning? Is Wu attackable?" 6 Shu and Wu ministers, Fei Yi 費禕 (d. 253), Zhuge Ke 諸葛恪 (203-253), and Xue Zong 薛綜 (d. 243), engaged in clever repartee in the form of verse in the four-syllable line. ${ }^{7}$ The Shu scholar Qin Mi 秦宓 (d. 226) famously came up with witty answers to a series of playful but challenging questions, such as "Pray, does Heaven have a surname?" posed by a Wu diplomat. ${ }^{8}$ While the representation of such verbal sparring depends on the viewpoint of the author recording it and thus perhaps ought to be taken with a grain of salt, it illustrates the discursive importance of such representation in the construction of the state's image.

At a more subtle level, Wei, Shu, and Wu all desired to be seen as the legitimate inheritor of the Han legacy. Regional identity is only flaunted in the sense that it makes one better suited to being the Han heir, such as in the Wu writers' poetic expositions to be discussed later. In Shu and $\mathrm{Wu}$, connection with prominent old families of the Han constituted considerable cultural capital and received mention as special distinction in a man's biography. ${ }^{9}$ Approval by members of those old families of the north is often cited as the demonstration of a man's cultural excellence and worth. ${ }^{10}$ As will be demonstrated in this article, Wu in

4. The Talent of Shu: Qiao Zhou and the Intellectual World of Early Medieval Sichuan (Albany, N.Y.: State Univ. of New York Press, 2007), 2-3.

5. For a detailed discussion of Cao Pi's self-representation, see Xiaofei Tian, "Material and Symbolic Economies: Letters and Gifts in Early Medieval China," in A History of Chinese Letters and Epistolary Culture, ed. Antje Richter (Leiden: Brill, 2015), 162-71.

6. Chen Shou 陳壽 (233-297), comp. Sanguo zhi 三國志 (Beijing: Zhonghua shuju, 1959), 47.1123.

7. Ibid., $64.1430,53.1250$.

8. Ibid., 38.976 .

9. Xu Jing 許靖 (150s?-222), the cousin of the Eastern Han celebrity Xu Shao 許劭 (150-195) known as an insightful arbiter of talents, received such high honor in Shu that it is said Zhuge Liang, the powerful regent, would bow down to him in greeting. His biography is given precedence of place in the Book of Shu (Shu shu 蜀書) in Sanguo zhi, even though he did not seem to have done much at all in Shu except for "taking delight in talented gentlemen, encouraging and accepting members of the younger generation, and being ever untired of 'pure discussions'" (Sanguo zhi 38.967). Cheng Bing 程秉 (fl. second to third century), a Wu scholar of the Classics, had studied with the famous classicist Zheng Xuan 鄭玄 (127-200) and was treated with great respect by the Wu ruler Sun Quan, who made him Grand Tutor to the Crown Prince (Sanguo zhi 53.1248).

10. For instance, Yu Fan 虞翻 (164-233), a southern native and a classicist, sent a copy of his commentary on the Classic of Changes to Kong Rong 孔融 (153-208), one of the "Seven Masters of the Jian'an Era," and received a letter from Kong Rong praising the work. The letter is duly excerpted and recorded in Yu Fan's biography. 
particular was in a position to contend with Wei in its cultural undertakings, notably in the areas of history writing and ritual music.

There is yet another, perhaps more important, way for us to rethink the cultural dynamics of the Three Kingdoms, namely, the way in which the textually prolific Wu provides an alternative, external perspective on the Wei and Shu. Many Wu writers were engaged in the writing of book-length socio-political treatises, in which they made keen observations of contemporary political events and personages. Zhang Yan 張數 (d. 266), Wu's Chamberlain for Dependences whose responsibilities included taking charge of diplomatic relations, offers a comparative analysis of the Shu and Wei ministers in his aptly titled Noted in Silence (Mo ji 默記). The work even preserves a memorial by Zhuge Liang that is missing from Zhuge's collection. Most remarkable is an anonymous Wu account of the warlord Cao Cao's life and career, known as “The Biography of Cao the Trickster" (Cao Man zhuan 曹瞞傳, “Trickster” supposedly being Cao Cao's childhood moniker). The account, written with flair, presents a vivid, complex picture of Cao Cao as a man of cunning, ruthlessness, and charisma. Copiously cited in the historian Pei Songzhi's 裴松之 (372-451) commentary on Sanguo zhi, it contains numerous colorful anecdotes that have since become character-defining and widely known in the late imperial literary representation of Cao Cao. Many of the anecdotes are not found in any other source, and the Cao Cao they depict - smart yet rakish, cool yet theatrical, an informal and easy-going man who laughed with his guests so heartily that he would bury his face in food, and yet deceitful, cruel, and terrifying beyond all measure — cannot possibly exist in the somber and deferential Wei narratives about their dynasty's founding father.

The external perspective on Wei found its culmination in the brothers Lu Ji 陸機 (261303) and Lu Yun 陸雲 (262-303), descendants of a prestigious southern clan. They were also the great-grandsons of Sun Ce 孫策 (175-200), one of Wu's founders and the elder brother of the first Wu emperor Sun Quan. After Jin conquered Wu in 280, Lu Ji and Lu Yun lived in reclusion at their southern home, and left for the capital Luoyang to serve in the Jin court only ten years later. Treated as outsiders there, they were keenly aware of being such, even as their literary talent won wide recognition and admiration. Both brothers had an intense sense of their southern roots, and yet both were deeply fascinated by the northern culture, especially by the Wei legacy. Of the two brothers, Lu Ji, doubtlessly the more innovative, exerted a profound influence on the Southern Dynasties poetry. Throughout the early medieval period he was regarded, rightly, as the most important poet after the Jian'an group. Compared to the northern poets Fu Xuan 傅玄 (217-278) or Zhang Hua 張華 (232-300), both also crucial figures in the late-third century literary scene, Lu Ji was unique in bringing his southern identity to bear on northern poetry, as he effected changes to the northern literary tradition in ways that only an outsider could.

This article begins with an overview of Shu and Wu literary production, and moves on to a more detailed discussion of Wu's cultural enterprises, namely history writing and especially the making of ritual music. I argue that both projects of history writing and music making were intended to assert Wu's legitimacy and cultural power vis-à-vis Wei and Shu's claims to cultural and political orthodoxy. The Shu and $\mathrm{Wu}$ perspectives provide a crucial link in Chinese literary history, and enable a fuller picture of the cultural dynamics of the Three Kingdoms period that, in the popular imagination, is famed for its military conflicts and spectacular battles.

In this article I use the terms cultural, literary, and textual production alternatively, with each denoting or stressing a different aspect of a state's engagement in its cultural missions as opposed to its martial operations, of which there were many in the Three Kingdoms period. Literary production refers to the production of belletristic writings in the narrower, 
modern sense of "literature" (wenxue 文學). Cultural production includes literary production, but also includes the writing of history and the making of ritual music, the sort of state enterprises that would not fall in the sphere of "literature" in the narrower sense of the word, although they are certainly considered part of the wen 文 (patterned or cultured) undertakings. Textual production refers to the production of written texts, be they commentaries on the classics, histories, or poetic writings; but clearly ritual music, save for the song lyrics, is not covered by this term.

\section{THE LITERARY PRODUCTION OF SHU}

Much of what we know about the cultural life of Shu comes from the Book of Shu in Sanguo zhi. The historian Chen Shou who was from Shu tried very hard to represent Shu in the best light possible. In the group biography of ten scholars, Chen Shou includes Xu Ci 許慈 and Hu Qian 胡潛, people who were much ridiculed by their contemporaries for engaging in petty fights and even coming to blows with each other over ritual matters. Sun Sheng 孫盛 (ca. 302-373), the Eastern Jin historian, explains: "Shu lacked cultured men, therefore the like of Ci and Qian all found their way into the [historical] record" 蜀少人士, 故慈潛等並見載述. ${ }^{11}$

The sentiment that Shu suffered from a shortage in human resources is echoed elsewhere. Another Eastern Jin historian, Xi Zuochi 習鏊齒 (d. 384), comments disapprovingly on Zhuge Liang's execution of Ma Su 馬謖 (190-228): “Shu was isolated and deprived, and its talents numbered far less than those of the Upper Kingdom; yet [Zhuge] slayed its remarkable man ... wouldn't it be hard for him [i.e., Zhuge] to succeed in his enterprise?" 12 When Zhuge Liang himself heard that Xu Shu 徐庶 (d. ca. 230s) and Shi Tao 石鞱 (fl. second to third century), both of whom he held in high regard, served in undistinguished positions in Wei, he said wistfully, "Wei truly has too many talented gentlemen, doesn't it! How come those two men are not employed [to their full ability]?"13

With a territory roughly corresponding to modern-day Sichuan but mostly occupied by nonHan peoples at that time, it must be said that Shu did not do badly for a province. Yet, when compared to Wei and $\mathrm{Wu}$, Shu was undeniably limited by its physical size and its resources, material and otherwise, and the fact that it had to constantly defend itself against its more powerful foes could not but have distracted the state from attention to cultural undertakings. Shu had once boasted of two of the greatest Han writers of poetic expositions, Sima Xiangru 司馬 相如 (179-117) and Yang Xiong 揚雄 (53 B.C.E.-18 C.E.). Its literary glory somewhat faded in the Eastern Han, even though, as Farmer has shown in his book, it was by no means devoid of scholarly and intellectual activities. ${ }^{14}$ Many Shu scholars had written commentaries on the classics, composed philosophical treatises, and, in the case of the erudite Shu intellectual Qiao Zhou 譙周 (ca. 200-270), produced discussions of ancient history as well. If, however, we turn our attention to Shu's belletristic writings, namely poetry and poetic expositions, the situation is not nearly as promising as in the area of scholarly and intellectual endeavors.

Examining the Sui shu 隋書 "Bibliography" section for individual literary collections (bieji 別集), we find no more than a small handful of titles recorded, by Zhuge Liang, Xi Zheng 郤正 (d. 278), Xu Jing, and Xiahou Ba 夏侯霸 (ca. 180s-250s), all of which are now lost. ${ }^{15}$ Notably, none of these four authors was a native of Shu. Instead, they were all northerners.

11. Cited in Pei Songzhi's Sanguo zhi commentary, in Sanguo zhi 42.1023.

12. Ibid., 39.984.

13. Ibid., 35.914.

14. See Farmer, The Talent of Shu, 15-30.

15. Sui shu (Beijing: Zhonghua shuju, 1973), 35.1060. 
Zhuge Liang was a descendant of an old official family from Langye 琅邪 (in modern Shandong). Xi Zheng's grandfather Xi Jian 郤儉 had served as Governor of Yizhou (modern Sichuan) and was killed by rebels in the turbulent last decades of the Eastern Han, so his father stayed on in Shu, where Xi Zheng was born. Xu Jing was from a distinguished northern family of Ru'nan 汝南 (in modern He'nan). Xiahou Ba was a Wei general related to the Caos, who had capitulated to Shu in 249 when the Sima clan slaughtered the regent Cao Shuang 曹爽 (d. 249) in a coup.

Whereas we do not know the content of Xu and Xiahou's collections, Zhuge Liang's prose seems to primarily consist of functional writings serving specific administrative or military purposes. Zhuge's collection was put together by none other than the historian Chen Shou himself and presented to the throne in 274. Chen's memorial to the throne accompanying the collection, with a list of chapter titles attached, has survived. The headings of the chapters are mixed: some chapters are organized in terms of genre and content, such as "Military Instructions" or "Letters to Sun Quan," whereas others are ordered by major events, such as "Southern Campaigns" and "Northern Crusades." Interestingly, in his memorial Chen defends Zhuge Liang's writings against accusations of lack of literary elegance:

Some critics complain that Liang's writings are lackluster in terms of literary elegance, but instead are rambling and long-winded. In your subject's humble opinion, Jiu and Gun were great worthies and the Duke of Zhou was a sage; when we examine the Book of Documents, Gaoyao's counsels are terse and graceful while the Duke of Zhou's announcement is wordy and exhaustive. Now why is that? It is because Jiu and Gun were discussing matters with [the sage emperors] Shun and Yu while the Duke of Zhou was swearing an oath with his underlings. Since those with whom Liang spoke were all ordinary people, his writings could not have been far-reaching and profound. ${ }^{16}$

論者或怪亮文彩不灎, 而過于丁寜周至。臣愚以為处繙大賢也, 周公聖人也。㪀之尚 書, 处繙之謨略而雅, 周公之誥煩而悉。何則? 处嗂與舜禹共談, 周公與宭下矢誓故 也。亮所與言盡眾人凡士, 故其文指不得及遠也。

Chen Shou contends that Zhuge Liang's writings must be cherished for his "public-mindedness and sincerity." Ultimately one of Zhuge Liang's memorials made its way into the Wen xuan. This memorial petitioning the throne for permission to go on a military campaign has become a widely anthologized piece ever since, but Chen Shou's defense of Zhuge Liang reminds us that Zhuge was by no means celebrated for his literary talent by the contemporary standard of belles lettres. Literary tastes and judgment changed over time.

Likewise of northern origin, Xi Zheng is the only one of the above-cited four authors who is said to have shown a keen interest in "literary writings" (wenzhang 文章). Books were apparently hard to come by in Shu: the Confucian scholars Xu Ci and Hu Qian, mentioned earlier, reportedly withheld books from each other; a Li Quan 李權 tried to borrow Zhanguo $c e$ 戰國策, by no means a rare title, from Qin Mi, but was rebuffed because Qin Mi did not consider it proper reading material for him. ${ }^{17} \mathrm{Xi}$ Zheng himself is said to have avidly searched for literary compositions by "Sima [Xiangru], Wang [Bao 王雍, 90 B.C.E.-51 C.E.], Yang [Xiong], Ban [Gu 班固, 32-92], Fu [Yi 傅毅, d. ca. 90], Zhang [Heng 張衡, 78-139], and Cai [Yong 蔡邑, 132-192]." He himself reportedly composed “about one hundred pieces of poetry, treatises, and poetic expositions." Xi's biography in Sanguo zhi includes an essay, "Dispelling Ridicule" (Shi ji 釋譏), modeled on a long tradition of such essays, typically set between a "host" and a "guest"—an imaginary interlocutor whose mocking questions afford

16. This memorial is attached to "The Biography of Zhuge Liang" in Sanguo zhi 35.931.

17. Ibid., 38.973 . 
the host an opportunity to explain and defend himself. ${ }^{18}$ No poem or poetic exposition by him remains.

The only poem we have that is reputedly by a Shu author and by a Shu native-Qin $\mathrm{Mi}$-appears in a dubious source more than a thousand years later; this is a poem in the fivesyllable line entitled "Far Roaming" (Yuan you 遠游). ${ }^{19}$ One may be tempted to conclude, then, that the lack of representation of Shu literature can be to a certain degree justified by the dearth of belletristic writings from the region during the Three Kingdoms period, but we will soon be disabused of such a notion if we turn our attention to $\mathrm{Wu}$.

\section{THE LITERARY PRODUCTION OF WU}

Under the category of literary collections ( $j i$ 集), the Sui shu "Bibliography" lists more than twenty collections by $\mathrm{Wu}$ authors. ${ }^{20} \mathrm{In}$ addition, there is a large number of classical commentaries and exegeses under the "Classics" (jing 經) category, monographs exploring social, political and philosophical issues under the "Masters" ( $z i$ 子) category, and, more important, works of historiography under the "History" (shi 史) category, to which we will return later. The most noteworthy writers are Zhang Hong 張紘 (153-212), Hu Zong 胡綜 (183-243), Xue Zong and his son Xue Ying 薛瑩 (d. 282), Hua He 華覈 (219-278), Min Hong 閔鴻 (fl. 240s-280s), and Yang Quan 楊泉 (fl. mid to late third century). Together they represent roughly three generations of $\mathrm{Wu}$ authors. A cultural luminary whose life spanned nearly the entire Wu rule, Wei Zhao, will be discussed in detail in the next section.

Zhang Hong was a native of Guangling 廣陵 (modern Yangzhou in Jiangsu), as was Chen Lin, one of the most respected writers in Cao Cao's entourage. His biography states that he had left more than ten fascicles (pian 篇) of poems, poetic expositions, inscriptions, and elegies. He kept up a correspondence with Chen Lin. Interestingly, in a wonderful mixture of modesty and arrogance, Chen Lin in a letter to Zhang Hong complains of the shortage of literary talent in the north as a way of explaining why he stands out as an excellent writer.

Since I went to the north of the River, I have been living in isolation from the world. People here lack ability in literary compositions and so it is easy to become a hegemon [in writing]. I have received your excessive praise, which does not reflect the truth. Now that Jingxing is here, while you, sir, and Zibu are over there-I feel like a little shaman meeting a master shaman, all my divine aura suddenly vanished. ${ }^{21}$

自僕在河北, 與天下隔, 此閒率少於文章, 易為雄伯, 故使僕受此過差之譚, 非其實 也。今景興在此, 足下與子布在彼, 所謂小巫見大巫, 神氣盡矣。

18. Ibid., 1034-38.

19. It appears in Yaoshan tang waiji 堯山堂外紀 compiled by Jiang Yikui 蒋一葵 (1594 juren), who does not give a source. Reprinted from a late Ming edition in Siku quanshu cunmu congshu 四庫全書存目從書, series 3, vols. 147-48 (Ji'nan: Qi Lu shushe, 1995), 147.471-72. According to Jiang's preface, the content of this work had been copied from various books, especially those "unofficial histories that are not [commonly] seen" 散见于 稗官野史不经人见也者 (147.384). The appended Siku quanshu editorial note says of the work: “The elegant and the vulgar are displayed side by side, and the authentic are next to the inauthentic: the compiler certainly had not exercised much judiciousness in his selections" 雅俗並陳, 真偽並列, 殊乏簡汰之功 (148.494). The poem is not included in Lu Qinli's 逯欽立 monumental collection, Xian Qin Han Wei Jin nanbeichao shi 先秦漢魏晉南北朝 詩 (Beijing: Zhonghua shuju, 1983).

20. A couple of authors are listed under the Eastern (or Latter) Han and a few under the Jin, but they either served mainly in the $\mathrm{Wu}$ court or spent their prime serving $\mathrm{Wu}$, and, most importantly, they were Wu natives.

21. Jingxing 景興 was the courtesy name of Wang Lang 王朗 (d. 228), an eminent member of the northern elite and the father of the renowned classical scholar Wang Su 王肅 (195-256). Zibu 子布 was the courtesy name of Zhang Zhao 張昭 (156-236), Sun Quan's most respected senior counselor, whose posthumous title was the "Cultured Marquis." Zhang Zhao enjoyed a high fame for his literary and scholarly accomplishments. Along with Zhang Hong, he drafted most of Sun Quan's documents and correspondences in Sun Quan's youthful years. 
Zhang Hong was also a noted calligrapher. "When he composed a letter to Kong Rong, he wrote it out with his own hand"; and Kong Rong, a man of immense cultural status whose endorsement is always duly recorded as a sign of social validation, expressed his appreciation in his reply: "Every time I hold up your letter and see your handwritten words, I feel such pleasure that I would smile to myself, for it is as if I again saw your person” 每舉篇 見字, 欣然獨笑, 如復酰其人也. ${ }^{22}$ A large part of Zhang Hong's “Fu on a Pillow of Precious Material” (Guicai zhen fu 瓌材枕賦), probably the very piece that was openly admired by Chen Lin, is preserved in the early seventh-century encyclopedia Classified Extracts of Literature (Yiwen leiju 蓺文類聚). ${ }^{23}$ Zhang Hong also composed two accounts with odes (ji song 紀頌), commemorating the Wu founding fathers Sun Jian 孫堅 (155-191) and Sun Ce respectively. Upon reading them, Sun Quan was reportedly much moved and commended Zhang for his "true knowledge" of the Sun family's legacy. ${ }^{24}$

In contrast to the case of Shu, the Book of Wu (Wu shu 吳書) in Sanguo zhi contains many instances of $\mathrm{Wu}$ authors composing the belletristic genres of poetry and poetic expositions. $\mathrm{Hu}$ Zong, who had been Sun Quan's study partner in his early adolescence, was in charge of drafting edicts and other official court documents during Sun Quan's reign. In 229, Sun Quan took the throne in response to the auspicious omen of a yellow dragon appearing at Xiakou 夏口 (in modern Hubei), and henceforth commanded a Great Standard of Yellow Dragon to be made. Hu Zong was commissioned to compose a fu on the Great Standard, which is included in Hu Zong's biography in $W u s h u .{ }^{25} \mathrm{He}$ was the author of an oath when Wu and Shu pledged an alliance against Wei. ${ }^{26}$

Most remarkably, Hu Zong forged three letters in the name of Wu Zhi 吳質 (177-230), the man now perhaps best known as the recipient of Cao Pi's famous letter lamenting the plague-stricken writers of the Jian'an era. A dear friend to Cao Pi, Wu Zhi was admired for his literary talent; he was also reportedly adroit in getting along with both of the contending Cao brothers, Pi and Zhi 曹植 (192-232). ${ }^{27}$ Three (authentic) letters by Wu Zhi, two addressed to Cao Pi and one addressed to Cao Zhi, are included in the Wen xuan, demonstrating that he was highly regarded for his letter writing, a skill requiring literary grace and a refined notion of human subtleties. Upon ascending the throne, Cao Pi placed Wu Zhi in command of the armies of You and Bing Prefectures on the northeast frontier. After Cao Pi died, a Wei capitulator to Wu suggested that Wu Zhi was mistrusted by the current Wei emperor, i.e., Cao Pi’s son, Emperor Ming 明帝 (r. 226-239). Hu Zong seized the opportunity to slander Wu Zhi. His forged "Wu Zhi letters" flow forth with a natural elegance and are peppered with nice psychological touches and physical details. They eloquently speak of Wu Zhi's desire to surrender to Wu, giving a specific account of why, and how, he plans to do so. ${ }^{28}$

22. Sanguo zhi 53.1246.

23. Ouyang Xun 歐陽詢 et al., Yiwen leiju 藝文類聚 (Shanghai: Shanghai guji chubanshe, 1999), 70.1217. Also see Quan hou Han wen 全後漢文, in Quan shanggu sandai Qin Han sanguo liuchao wen 全上古三代秦漢三 國六朝文, ed. Yan Kejun 嚴可均 (Beijing: Zhonghua shuju, 1996), 86.939. Wei Zhao’s Wu shu, cited in Pei Songzhi's commentary: "When Hong saw a pillow made of nanliu wood, he loved its pattern, and composed a fu on it. Chen Lin, who was in the north at the time, read the $f u$ and showed it around, telling everyone, 'This was written by Zhang Zigang [Zhang Hong's courtesy name], a man from my hometown.'” Sanguo zhi 53.1246.

24. Sanguo zhi 53.1244 .

25. Ibid., 62.1414 .

26. This oath is in Sun Quan's biography in the Wu shu. Ibid., 47.1134-35.

27. Ibid., 21.607.

28. Ibid., 62.1414-17. 
These are the first known letters forged by a known writer to slander an enemy of a foreign state for political and military purposes; they deserve attention from literary scholars as a remarkable set of daizuo 代作 in prose letters that might have had-and at least were intended to produce-serious real-life consequences for the person being impersonated, and as such they differ from the poetic form of impersonation of a person's voice commonly seen in the third century. ${ }^{29}$ Fortunately for Wu Zhi, by the time these forged letters went into wide circulation, he had already been called back to the capital from his frontier military post and was made Palace Attendant, a court position close to the throne. He died shortly afterward in the summer of 230.

$\mathrm{Hu}$ Zong's namesake, Xue Zong, was another important minister as well as a prominent writer. According to his biography, he had "composed poetry, poetic expositions, "challenges,' and discussions in several tens of thousands words, naming them 'Carried with Partiality' [Si zai 私載]." 30 The term si zai originates from Confucius' remark in $L i j i$ 禮記 (Record of Rites): "Heaven covers without partiality; earth carries without partiality; the sun and moon illuminate without partiality." 31 Xue Zong seems to be saying that his writings are being "carried with partiality." Does it mean that he regarded his own compositions with particular favor? Or are his writings made to carry his favorite ideas? It is hard to tell with certainty. Some assume that Si zai is the title of Xue's collected writings, and if so, then Xue Zong is the first writer we know of who gave a title to his literary collection, and the title might simply be a playful reference to his compositions as textual containers that, unlike the impartial earth, carry one individual's words and ideas.

Xue Zong's other noteworthy achievement is his commentary on the Eastern Han author Zhang Heng's poetic expositions on the two capitals, which is frequently referenced in Li Shan's 李善 (630-689) influential Wen xuan commentary. In the Tang dynasty, Xue Zong's collection still survived in three scrolls, but was subsequently lost. ${ }^{32}$ His extant writings mainly consist of memorials to the throne and a number of odes (song 頌) in the four-syllable line on auspicious animals such as unicorns, phoenixes, and red and white ravens, preserved in encyclopedic sources. ${ }^{33}$

Xue Zong's second son, Xue Ying, inherited Xue Zong's literary talent. Sun Hao 孫 皓 (242-284, r. 264-280), the last Wu ruler, came across Xue Zong's writings in 271 and admired them; thereupon he commanded Xue Ying to compose a piece "in continuation [of his father Zong's work]." Xue Ying composed a long poem in the four-syllable line, narrating in detail a history of his father's and elder brother's service and debt to the Wu rulers, and ending predictably with an oath of repayment and loyalty. The poem has survived in its entirety in Xue Ying's biography. ${ }^{34}$ Sun Hao, however, was as capricious as he was ruthless, and Xue Ying was punished several times for real or imaginary offenses. Xue Ying's last service to Wu was the drafting of the letter of capitulation when the Jin army was at the door. Received with dignity at Jin court, he died shortly after, leaving behind a literary collection

29. One thinks of the five-syllable-line poem by Cao Pi on behalf of a Wei general's abandoned wife (Yiwen leiju 29.514). One also thinks of Lu Ji's poems written on behalf of his friend Gu Rong 顧榮 (d. 312) and Gu's wife (Lu Qinli, Xian Qin Han Wei Jin nanbeichao shi 5.682). Of course there might have been daizuo letters in the voices of historical personages from this period, but we do not know the name of the actual author as in the case of Hu Zong's forged "Wu Zhi letters."

30. Sanguo zhi 53.1254 .

31. Li ji zhushu 禮記注疏 51.861, in Shisanjing zhushu 十三經注疏, comp. Ruan Yuan 阮元 (Taibei: Yiwen yinshuguan, 1955).

32. Xin Tang shu 新唐書 (Beijing: Zhonghua shuju, 1975), 60.1581.

33. See Quan sanguo wen 全三國文 66.

34. Sanguo zhi 53.1254-55. 
in three scrolls, a work of history (of which more will be said in the next section), and a monograph in eight chapters entitled New Discussions (Xin yi 新議). His son Xue Jian 薛兼 (d. 323) was known, along with Min Hong and three others, as the "Five Prodigies" (wujun 五㩦) of $\mathrm{Wu}$, and served Jin with distinction. ${ }^{35}$ The Jin historian Wang Yin 王隱 (fl. early third century) comments on him admiringly, though with the typical northern condescension: "His credentials and reputation were just like that of a man from the upper domain and did not at all resemble that of someone from Wu” 資望故如上國, 不似吳人. 36

When Xue Ying was exiled to Guangzhou by the last Wu ruler, Hua He had petitioned the throne for his pardon, citing the reason that Xue Ying "is broad in learning and particularly skillful in literary writings; he is the top one of his colleagues. Although I see many ministers today who are erudite in studies of the Classics, when it comes to the talent of recording and transmitting, people like Ying are few and far between” 瑩涉學既博, 文章尤妙, 同寮之 中, 瑩為冠首, 今者見吏雖多經學, 記述之才如瑩者少. ${ }^{37}$ Among Wu authors there was a keen awareness of the different sorts of talents suitable to different sorts of writings. Much in the same way as Cao Pi evaluates the "Seven Masters," Hu Chong 胡沖 (fl. 243-after 280), Hu Zong's son and the author of a historical work Wu li 吳曆, commented on Hua He and Wei Zhao: "Hua He's talent in poetry and poetic exposition surpasses Yao's [i.e., Wei Zhao's], but in drafting edicts and pronouncements he falls short” 華覈詩賦之才, 有過於 曜, 典誥不及也. ${ }^{38}$

Like Zhang Hong, Hua He was a native of $\mathrm{Wu}$. He was one of the five ministers whom Sun Quan had entrusted with the task of compiling Wu's history. During Sun Hao's reign he was made the Right Historian of the State. "Because of his seniority, Sun Hao decreed that he write his memorials in cursive script, but Hua did not dare. Hao then commissioned him to compose a piece in cursive script." The "piece" was cited in Hua's biography; it is, by all appearances, a poem in the four-syllable line. ${ }^{39}$ Remarkably, however, Hua He left a fragmentary poem in the five-syllable line, known simply as "To Xue Ying." This is one of the very few private poems in the five-syllable line by a known Wu author. Only one couplet is preserved in Li Shan's Wen xuan commentary:

存者今惟三

飛步有匹特

Of those who have survived, there are just three today:

Hurrying along, they are a match for one another. ${ }^{40}$

Incidentally, we have two couplets from a poem “Reply to Hua Yongxian” 答華永先 (Yongxian being Hua He's courtesy name) by Xue Ying, the only other private five-syllable-line poem from $\mathrm{Wu}$. These couplets are found under the sub-category of "Joining the Army" (Congjun 從軍) in the tenth-century encyclopedia Taiping yulan:
桴鼓常在側
筆研永欲捐
卷衰不復開
干戈以為權
The war drum is always by my side;
brush and inkstone are ever forsaken.
Scrolls are rolled up, spread out no more.
Instead shield and halberd are held in hand. ${ }^{41}$

35. Jin shu 晉書 (Beijing: Zhonghua shuju, 1974), 68.1832.

36. See Pei Songzhi's commentary cited in Sanguo zhi 53.1256.

37. Sanguo zhi 53.1256 .

38. Li Fang 李昉 et al., Taiping yulan 太平御覽 (Taibei: Taiwan shangwu yinshu guan, 1975), 445.2177. This passage is quoted in the historian's comment with slight variation in Sanguo zhi 65.1470.

39. Sanguo zhi 65.1469 .

40. Wen xuan 31.1448 .

41. Taiping yulan 328.1636. 
We cannot know for sure that these two fragments are initially from a pair of "presentationresponse poems" (zengda shi 贈答詩). Nevertheless, a passage from Hua He's memorial to the throne pleading for Xue Ying's pardon might shed some light on the contents of the original poems:

At the time of the Young Emperor [r. 252-258], His Grace further commanded the five of usWei Yao [Zhao], Zhou Zhao, Xue Ying, Liang Guang, and my humble self-to seek and trace past events. That which we compiled and established together finally had a complete beginning and ending. But then, Zhao and Guang had died first; Yao [i.e., Wei Zhao] lost imperial favor by committing a crime [in 273]; and Ying was sent out of the capital to be a general and then was banished for an offense. The book project was henceforth left unfinished, and so far has not been presented to the throne. ${ }^{42}$

至少帝時, 更差韋曜、周昭、薛瑩、梁廣及臣五人訪求往事, 所共撰立, 備有本末。 昭、廣先亡, 曜負恩蹈罪, 瑩出為將, 復以過徙。其書遂委滯, 迄今未撰奏。

It would seem that Xue Ying's poem above was about his unhappy experience of being sent away from the capital to be a military man in Wuchang (in modern Hubei), and that Hua He's poem might very well have been about the three survivors from the team of five historians.

The last two Wu authors to be mentioned in this brief survey of Wu literary production are Min Hong, who served as Palace Attendant in Wu, and Yang Quan, a recluse. Both men had survived Jin's conquest of Wu in 280 and were subsequently summoned by the Jin court, but both refused to serve. Yang Quan was the author of Discourses on the Principle of Things (Wuli lun 物理論), a book-length "knowledge text" of sixteen scrolls; many fragments are extant through encyclopedia sources. Both authors have left behind a number of remarkable poetic expositions on topics of a distinctly regional flavor and with great contemporary significance.

Min Hong's “Fu on Personally Tending Silkworms” (Qincan fu 親䖯賦) is on a ritual ceremony to be performed annually in early spring by the empress, who personally participated in the sericultural activity of picking mulberry leaves and feeding the silkworms, known as qincan 親虽 or qinsang 親桑. The ritual was the counterpart of the emperor's ritual performance of plowing the field (qingeng 親耕 or jitian 籍田). The plowing ceremony, which can be traced back to the Zhou dynasty, was observed through the Han alongside the empress' ritual affirmation of sericulture. ${ }^{43}$ Incidentally, Yang Quan also wrote a $f u$ on silkworms (Can fu 蛀賦). In the preface Yang states that many ancients had composed poetic expositions but no one ever wrote on silkworms; in the poetic exposition itself, however, it is clear that he is writing not just about silkworms, but also about the ritual of qincan. It is worth noting that Cao Pi had established the silkworm ritual in the Wei court in the spring of 226, just a few months before his death and four years after Sun Quan proclaimed himself emperor. ${ }^{44}$ It seems that the Wu court had established the same sericultural ritual in an attempt to perform and affirm its political legitimacy. Min Hong's and Yang Quan's poetic expositions both testify to the $\mathrm{Wu}$ subjects' intense awareness of the ritual significance of the sericultural ceremony in the making of the state.

A poetic exposition by Yang Quan, on the very "southern" topic of the "Five Lakes" (Wuhu fu 五湖賦), was no doubt also intended as a deliberate contestation of the northern

42. Sanguo zhi 53.1256 .

43. A later poetic exposition celebrating the imperial plowing ceremony was written by the Western Jin writer Pan Yue 潘岳 (247-300) and is included in the Wen xuan.

44. Jin shu 19.590 . 
dynasty's claim to central political and geographical importance. ${ }^{45}$ This exposition has a preface explicitly stating the author's pro-south attitude:

I observe the main body of the Five Lakes and investigate its scenery: how majestic and magnificent! In my opinion, famous mountains and great marshes must have writings to record and eulogize them. Therefore Mount Liang has the Poem "Great" and Yunmeng has the poetic exposition of Zixu. ${ }^{46}$ As for the Great Lake, it is the grand floodplain of Yangzhou. ${ }^{47}$ It has the remaining traces of Yu the Great; it has the merit of dredging the rivers and channeling the blockage; and yet, it had never been graced with the beauty of brush and ink. Incensed by the injustice of this, I have ventured to ignore my own lack of talent and offered an exposition on it.

余觀夫主五湖而察其雲物, 皇哉大矣。以為名山大澤必有記頌之章, 故梁山有奕奕之詩, 雲 夢有子虛之賦。夫具區者, 揚州之澤藪也。有大禹之遺迹, 疏川導滯之功, 而獨關然未有翰 墨之美, 余䈪憤焉。敢忘不才, 述而賦之。

The claim to write a $f u$ on a topic that no previous author has written on is something we begin to see in the Eastern Han. Making a statement about being "the first" in the prefaces to his poetic expositions on silkworms and on the Great Lake, Yang Quan seems to have a particularly strong desire for novelty. While the desire for novelty is usually tied to an equally strong sense of literary history and to conscious self-positioning, in Yang Quan's case the self-positioning is both literary-historical (that is, in terms of his awareness of the poetic tradition) and geopolitical (that is, in terms of his desire to glorify the state of $\mathrm{Wu}$ ).

The pride about Wu identity is also revealed in Min Hong's " $F u$ on the Feather Fan" (Yushan fu 羽扇賦). Fans commonly used in the north were either square or round, made of bamboo and silk; in contrast, Wu fans had a different shape and texture, as they were often made of bird feathers, such as those of a crane. Wu's regional product - the feather fan-was to become a fashionable accessory in the northern capital Luoyang after Jin's conquest of $\mathrm{Wu}$, and many northern writers wrote poetic expositions about it as an exotic object from a newly subjugated state. ${ }^{48}$ Min Hong's piece closely relates the feather fan to its origin, the crane, exalted as a noble bird. Throughout the fragment we hear echoes of the classics, espe-

45. A number of fragments survive in encyclopedia sources. The largest chunk of this fu is from Yiwen leiju 9.169. The preface is preserved in another Tang encyclopedia, Chuxue ji 初學記 (Beijing: Zhonghua shuju, 1962), 7.141. "Five Lakes" was another name for Taihu 太湖, the Great Lake, in present-day Jiangsu and Zhejiang. Zhang Bo's 張勃 (fl. late third century) Wu lu 吳錄, for instance, notes that Wuhu is “another name for Taihu." Cited in Li Shan's Wen xuan commentary on Guo Pu 郭璞 (276-324), “Fu on the Yangzi River" 江賦.

46. The Shi jing poem beginning with the line “Great is Mount Liang”奕奕梁山 is entitled “Hanyi” 韓奕. Mao shi zhushu 毛詩注疏 18.679, in Shisanjing zhushu. The poetic exposition of Zixu refers to Sima Xiangru's famous "Zixu fu."

47. Yangzhou here is used in the ancient sense of one of the Nine Provinces in southeastern China after Yu the Great tamed the flood.

48. These writers include Fu Xian 傅咸 (239-294), Xi Han 秽含 (262-306), and Pan Ni 潘尼 (ca. 250-311). Fu Xian's preface to his " $F u$ on the Feather Fan" and Xi Han's preface to his $f u$ make it clear that these writings were composed after the conquest: "The Wu folk take the plumes from a bird's wings to produce wind. It is superior to the square and round fans, but no one in the Central Kingdom was interested in it. After the conquest of $\mathrm{Wu}$, however, it suddenly becomes a prized thing” 吳人截鳥翼而搖風, 既勝于方圓二扇, 而中國莫有生意. 滅吳之後, 翕然貴之 (Fu Xian); and “Qin conquered the domain of Zhao in the past and brought back Zhao's official attire to ... its courtiers; after the great Jin subjugated Wu, it likewise took Wu's feather fan and put it to use in the upper domain” 昔秦之兼趙, 寫其冕服以 $\square$ 侍臣; 大晉附吳, 亦遷其羽扇 御于上國 (Xi Han; the lacuna is original). Quan Jin wen 全晉文 51.1752, 65.1830. Pan Ni's piece contains the following lines: “At first, it demonstrated its usefulness in the barbarian wasteland; / But eventually it manifests its wonder in the upper domain” 始顯用于荒 蠻, 終表奇于上國. Quan Jin wen 94.2000. Zhang Zai 張載 (ca. 250-ca. 310) wrote a fu of the same title, but from its fragments it is not easy to see any particular association with the Jin conquest of Wu (Quan Jin wen 85.1949). 
cially the Classic of Poetry, and the use of the canonical texts from the Central Plain lends an air of traditional elegance and dignity to the southern product.

\begin{tabular}{|c|c|}
\hline 惟羽扇之做興 & Where does the feather fan originate? \\
\hline 乃鳴鴻之嘉容 & From the fine form of the crying crane. ${ }^{49}$ \\
\hline 產九畠之中澤 & It is born in the middle of the nine-bending marsh, \\
\hline 雍喈之天聰 & Its melodious voice reaches afar to imperial hearing. ${ }^{50}$ \\
\hline 高義於大易 & It manifests noble principles in the great Changes; ${ }^{51}$ \\
\hline 詩人之雅章 & It is noted in the Poet's elegant stanzas. \\
\hline 系茲翮以内飛 & It relies on these feathers to aid its inner ability of flight; \\
\hline 儀於外揚 & Its plumage shines forth without, a model to all. \\
\hline 時 & At the time \\
\hline 融持運 & Zhurong is holding power; ${ }^{52}$ \\
\hline 上明發揮 & His vermilion light surges forth. \\
\hline 陽衝布 & The galloping sun penetrates in its spreading; \\
\hline 炎赫䂀 & Its flying flames burn bright and majestic. \\
\hline 司煴隆於雲漢 & We feel the great heat of the "Milky Way" 53 \\
\hline 慘毒於中懷 & And share the suffering and misery. \\
\hline 乃 & Thereupon \\
\hline 爽塏 & We climb onto a high land, \\
\hline & And come upon a sweet spring; \\
\hline & Rinsing our mouths with the clear stream, \\
\hline & And shaded by the dark cloud. \\
\hline & Leisurely, casually, we work this weightless thing of delight, \\
\hline 於自然 & It bestirs a clear breeze all on its own; \\
\hline & We open the gauze lapels and let it into our bosoms, \\
\hline & As it flusters the silk tassels of our caps. \\
\hline & The seated guests are delighted and charmed, \\
\hline & All tap beats with a common cheer. \\
\hline & Moved by the perfumed wind stirring our bosoms, \\
\hline & We chant of the "Heart of the Jujube Tree." 54 \\
\hline & Thereupon \\
\hline & The scorching air melts away, \\
\hline & Only then do the host and guests begin the toasting ritual. \\
\hline & We rest our spirit and quiet our thought, \\
\hline
\end{tabular}

49. The word I translate as crane is hong, usually referring to the wild goose or swan. It is Min Hong's personal name. I have rendered hong as crane because the next line mentions "nine-bending marsh," which is an allusion to the Shi jing poem, "Crane Cries" ("He ming” 鶴鳴), cited in the next note.

50. The Shi jing poem "He ming" begins thus: "The crane cries in the nine-bending marsh; / Its voice is heard all over the wilderness” 鶴鳴于九泉, 聲聞于野. The lines are traditionally interpreted as depicting a recluse who, though living in reclusion, has a far-reaching reputation. Mao shi zhushu 11.376.

51. The singing crane is featured as an image of established virtue and trust in the "Zhongfu" 中孚 ("Inner Trust") Hexagram in the Classic of Changes: "The crane cries in the shadows; / Its young answer it." See Zhou Yi zhushu 周易注疏 6.133, in Shisanjing zhushu.

52. Zhurong is the god of fire in ancient mythology and the god of the South. Here the line is simply talking about summer.

53. The Shi jing poem "Yun han" 雲漢, which laments a serious drought, begins with gazing at the starry sky at night and hoping to detect the sign of a coming rain. Mao shi zhushu 18.659 .

54. This refers to another Shi jing poem, "Kaifeng”凱風: “A gentle breeze from the south / Blows on the heart of the jujube tree” 凱風自南吹彼棘心. Ibid., 2.85 . 


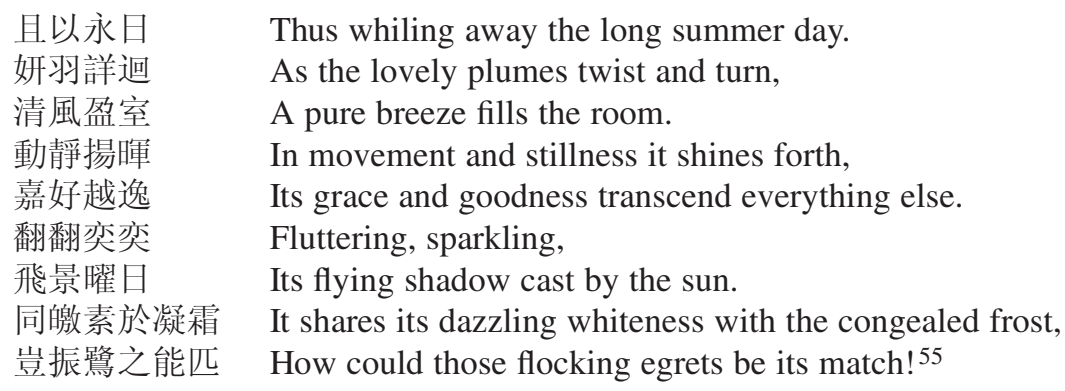

Using a plethora of classical allusions, Min Hong demonstrate that the feather fan, the distinctly regional product from the fiery south, the land of Fire and of Vermillion Light, is in fact more "northern" than the north: it embodies the spirit of the classics and, in terms of its function (i.e., bringing cool) and its color (i.e., white), exemplifies the cold north of the yin energy. Bird and fan are conflated with each other in a remarkable depiction in the last eight lines, as the fluttering of the fan mimics the fluttering wings of the crane and generates a clear breeze, and light and shadow are intertwined in an image of the dazzling whiteness of the frost, which is said to far surpass the white egret of the Shi jing poem symbolizing "a pure gentleman" serving in the king's court. Min Hong's feather fan thus may be said to possess the best of both worlds, that is to say, both the north and the south.

It is not clear whether Min Hong's piece had been written before Jin's conquest of Wu or after the conquest in response to the northern writers. In the former case, he would have written with prescience, though he would also be writing in a long tradition of poetic expositions on fans. ${ }^{56}$ If the latter case is true, then we see, in a Wu writer who chose never to go to Luoyang and serve in the Jin court, a continuous cultural contestation between north and south, even after the war of the Three Kingdoms was over on the battlefield. The clash between north and south is manifested even more clearly in $\mathrm{Lu} \mathrm{Ji}$, the author of another " $F u$ on the Feather Fan" who did go to Luoyang and serve, ${ }^{57}$ and in Ji's younger brother Yun, who as a young boy had met Min Hong and was praised by Min as "either a dragon pony or a phoenix chick." ${ }^{58}$ It is a clash with a new twist and has been well explored elsewhere. ${ }^{59}$

Wu had had many men of letters working as scholars, historians, and authors of poetry and poetic expositions. In contrast to the northern émigrés who came to represent Shu literary production, many of these authors were Wu natives. In Min Hong's and Yang Quan's works we witness a desire to assert the glory of Wu by demonstrating Wu's close ties with

55. The "flocking egrets" 振鷺 refers to a Shi jing poem of the same name. Ibid., 19.730.

56. Cao Zhi had composed a “Fu on the Nine-Splendor Fan" (Jiuhua shan fu 九華扇賦), which has a preface describing a bamboo fan given to Zhi's adopted great-grandfather Cao Teng 曹騰 (100-159), the eunuch attendant in the palace, by Emperor Huan of the Han (r. 146-168). Quan sanguo wen 14.1128. Cao Zhi's writings seem to have been well known in $\mathrm{Wu}$, and one wonders if Min Hong might have been inspired by it. The tradition of writing about fans can be traced back to much earlier writers, and Cao Zhi's fu itself is part of that tradition.

57. For a translation and discussion of Lu Ji's fu, see David R. Knechtges, "Southern Metal and Feather Fan: The 'Southern Consciousness' of Lu Ji," in Southern Identity and Southern Estrangement in Medieval Chinese Poetry, ed. Ping Wang and Nicholas Morrow Williams (Hong Kong: Hong Kong Univ. Press, 2015), 36-41. If, as Knechtges argues, Lu Ji's $f u$ is "an exposition in the style of the Wei-Jin period xuanxue thinkers" (p. 40), perhaps intended to demonstrate Lu's mastery of the metaphysical discourse on Laozi and Zhuangzi that was so popular among the elite of Luoyang, then Min Hong's $f u$ is certainly much more of a composition deeply immersed in the study of the classics, which had characterized the traditional scholarship of Wu.

58. Jin shu 54.1481.

59. See Xiaofei Tian, "Fan Writing: Lu Ji, Lu Yun and the Cultural Transactions between North and South," in Southern Identity and Southern Estrangement, 43-78. 
the classical tradition of the Chinese heartland in the north. Wu writers also seem to have largely preferred and excelled in the four-syllable line, the meter most commonly used in the Classic of Poetry and perceived as possessing classical elegance and archaic formality. This is in glaring contrast with the five-syllable line verse form, a low genre at the time, prevailing in the Luoyang area and favored by the Cao family and its followers. ${ }^{60}$ However, when we come to the third generation of the Wu writers such as Hua He and Xue Ying, we begin to see the first instance of versification in the five-syllable line in Wu. We know that Cao Pi had given a copy of his literary writings and his Normative Discourses to Sun Quan and another copy to Zhang Zhao, ${ }^{61}$ and that Lu Ji had already read Cao Zhi's literary collection before he went to Luoyang. Presumably northern poetry and poetic exposition had gradually infiltrated the Wu elite by the mid-third century.

Of the three kingdoms, Shu was guided by Zhuge Liang's belief that, if Shu did not direct all of its efforts and resources first and foremost to the military front, it would have been easily overwhelmed by its two strong enemy states. ${ }^{62} \mathrm{Wu}$ and Wei, however, consciously competed with each other in the cultural sphere. In the following section I will explore two major aspects of this competition in the public realm of the Kingdom of $\mathrm{Wu}$.

\section{WRITING HISTORIES}

The first major aspect of Wei and Wu's competition for political legitimacy and cultural power is the writing of dynastic history. When the Jin dynasty fell to the invasion of non-Han peoples and was reestablished in the former Wu capital Jiankang 建康 (modern Nanjing) in 317 , one of the first things that the founding emperor of the Eastern Jin did was to establish a History Bureau in response to the urgent plea made by the prime minister Wang Dao 王導 (276-339). In his memorial to the throne, Wang Dao describes the compilation of dynastic history as the act of "spreading the accomplishments of the ancestors and recording the merits of ministers who had assisted in the founding of the dynasty," of "satisfying the expectation of all people and delighting the hearts of gods and men," and of "being truly the utmost manifestation of peace and prosperity, and the great foundation of the kingly enterprise" 上 敷祖宗之烈, 下紀佐命之勳 ... 厭率土之望, 悅人神之心, 斯誠雍熙之至美, 王者之弘基 也. ${ }^{63}$ As Wang Dao's words show, to produce a history of the realm, particularly an account of the founding of the dynasty, was regarded as a project of great political importance.

Of the Three Kingdoms, it seems that only Wei and Wu had established the historian's office. Under the category of "History," the Sui shu "Bibliography" offers an account of history writing throughout the ages, stating: "When the Three Kingdoms formed their tripod positions, Wei and Wu both had had officers in charge of history” 及三國鼎峙, 魏氏及吳並 有史官. ${ }^{64}$ According to Hua He,

60. Strikingly, when Wang Can 王粲 (177-217), the most illustrious of the "Seven Masters of the Jian'an era," presented poems to his friends when he was at Jingzhou 荊州 (in modern Hubei), the poems were composed in the four-syllable line; but after he joined Cao Cao's staff and went north, most of his extant poems are in the fivesyllable line.

61. According to Hu Chong's Wu li, cited in Pei Songzhi's Sanguo zhi commentary, the set of writings sent to Sun Quan was copied on silk while that to Zhang Zhao was on paper. Sanguo zhi 2.88.

62. Zhuge Liang's belief is expounded in a memorial presented to the throne in 228; this memorial is preserved in Zhang Yan's Mo ji. It is cited in Pei Songzhi's commentary on Zhuge Liang's biography in Sanguo zhi (35.923). Zhang Yan endorses and echoes these sentiments in his Mo ji. Sanguo zhi 35.935-36.

63. Jin shu 82.2149 .

64. Sui shu 33.957. 
the Great Wu received Heaven's Mandate and founded the state in the southern land. In the last year(s) of the August Emperor [Sun Quan], His Majesty ordered the Grand Historian Ding Fu and the Gentleman of the Palace Xiang Jun to begin compiling the Wu History. ${ }^{65}$

大吳受命, 建國南土。大皇帝末年, 命太史令丁孚、郎中項峻始撰吳書。

Although Hua He describes Ding Fu and Xiang Jun as possessing no talent for history writing, their drafts were clearly useful to their successors and might have even survived independently into the fourth century. ${ }^{66}$ It is unclear whether by monian 末年 Hua He is referring to the last year of Sun Quan's rule—-the year 252—or a more vague period, "last years," but shortly after Sun Quan's heir Sun Liang 孫亮 (i.e., the Young Emperor) took the throne in 252, Zhuge Ke petitioned the throne to appoint Wei Zhao as the Grand Historian. Zhuge Ke was subsequently entrusted with the compilation of the Wu History along with Hua He, Xue Ying, Zhou Zhao, and Liang Guang. ${ }^{67}$ In 273, when the last Wu ruler Sun Hao imprisoned Wei Zhao, Hua He tried to use the project to save Wei from execution:

Also, although the Wu History already has a framework, the encomia have not been written. In the past, Ban Gu's Han History is elegant and refined in its diction; later, Liu Zhen and Liu Yi composed the Han Record, but it is far inferior to Ban Gu's work, and its encomia are particularly inadequate. The Wu History should be passed down for a thousand years and take its place among the various histories; talented men of the future will discuss and rank them according to their merits and demerits. We must have a fine writer like [Wei] Zhao in order not to leave an immortal work unfinished. ${ }^{68}$

又吳書雖已有頭角, 敍贊未述。昔班固作漢書, 文辭典雅, 後劉珍、劉毅等作漢記, 遠 不及固, 敍傳尤劣。今吳書當垂千載, 編次諸史, 後之才士論次善惡, 非得良才如曜 者, 實不可使䦕不朽之書。

Hua He tried his best to save his friend from ruin, but the Wu History appears to have been fairly complete by this point. Although it is no longer extant in its entirety, Pei Songzhi cites from it numerous times in his Sanguo zhi commentary. The citations in many cases reveal a $\mathrm{Wu}$ perspective on events both southern and northern, and such a perspective would have otherwise been missing from Sanguo zhi proper. ${ }^{69}$

In the year 255, shortly after the Wu rulers commissioned the compilation of a Wu history, the Wei court appointed Wang Chen 王沈 (d. 266) to work with Xun Yi 荀顗 and Ruan $\mathrm{Ji}$, the famous poet, to compile a Wei History (Wei shu 魏書). One is tempted to regard this appointment as a countermove responding to Wu's initiative. The work was considered to have "made many concessions to observe contemporary taboos, not as accurate as Chen

65. Sanguo zhi 53.1256 .

66. Yu Xi 虞喜 (281-356), descendant of the Wu classicist scholar Yu Fan, in his Zhi lin 志林 gives a discussion about why the first Wu prime minister, Sun Shao 孫邵 (163-225), does not have a biography in Wu's history: Yu Xi cites his contemporary Liu Shengshu 劉聲叔, a “gentleman of broad learning,” who claims that Xiang Jun and Ding Fu's records did indeed contain an account of Sun Shao, but since the later compiler Wei Zhao sided with Sun Shao's political enemy, Zhang Wen, he excluded it. Yu Xi's account seems to imply that his contemporary Liu Shengshu had seen a copy of Xiang Jun and Ding Fu's records. Sanguo zhi 47.1132.

67. Ibid., 65.1461-62: "Sun Liang took the throne and Zhuge Ke was regent; he memorialized the emperor asking to appoint Yao [Wei Zhao] as the Grand Historian to work on the Wu history, with Hua He, Sun Ying, and so forth all participating in the project” 孫亮即位, 諸葛恪輔政, 表曜為太史令, 撰吳書, 華覆、薛瑩等皆與參同.

68. Ibid., 65.1464 .

69. For instance, the first time $W u$ shu is cited in Pei's commentary is to supplement the narrative about Tao Qian's 陶謙 (132-194) role in the death of Cao Cao's father, Cao Song 曹嵩 (d. 193). Cao Cao's Sanguo zhi biography claims that Cao Song was killed by Tao Qian, Governor of Xuzhou, but Wu shu claims that it was Tao's subordinate who murdered Cao for his possessions and subsequently fled, and Cao Cao assigned the blame unjustly to Tao Qian instead. Ibid., 1.11. 
Shou's factual record” 多為時諱, 未若陳壽之實錄也. ${ }^{70}$ Cited throughout Pei Songzhi's commentary, it is nevertheless an important source for Wei's history, perhaps less for "objective facts" than for the viewpoint it provides on historical events.

Far more than Wei courtiers, Wu authors notably devoted much energy to compiling histories of the Eastern Han. Certainly this was as much a scholarly undertaking as a politically meaningful choice, as Wu saw itself as a rightful successor of the Han. Xie Cheng 謝承 (182-254), Sun Quan's brother-in-law, authored a History of the Latter Han (Hou Han shu 後漢書) while Wei Zhao's Comprehensive Record (Dong ji 洞紀) is an ambitious chronicle of events from the "beginnings" of Chinese history down to 222 C.E., the founding of the $\mathrm{Wu} .{ }^{71} \mathrm{Wu}$ authors also produced many biographies of local worthies; the aforementioned Xie Cheng, for instance, compiled the Biographies of the Former Worthies of Kuaiji 會稽 先賢傳. Wu writers also produced records of exotica from the far south, demonstrating their interest in regional geography and the customs of southern locales, as well as records of Wu's colonial explorations. Of the last category, the most remarkable specimens are those written by Zhu Ying 朱應 and Kang Tai 康泰 of their missions to Southeast Asia. ${ }^{72}$ This is no place to give a detailed review of Wu's public and private historical undertakings; suffice it to point out that $\mathrm{Wu}$ men of letters were very active in history making; their interest in state history is also distinguished by a fascination with the explorations of the geography, customs, and products of southern localities in an attempt to construct the southern empire. ${ }^{73}$

\section{CREATING SONGS}

For both Wei and Wu, history writing was a multi-media activity. The second major aspect of their competition for political legitimacy and cultural power was the making of music-more precisely, the making of the state history in musical form. In its intense concern with ritual and music, the Wei court engaged in a reworking of Han court music —or whatever was left of it—to serve the new dynasty's needs. Most significant is a set of twelve songs, the "Wei Songs for Drum and Fife" (Wei guchui qu 魏鼓吹曲), whose lyrics were composed by Miao Xi 繆襲 (186-245), scholar, ritual specialist, and writer.

Each song in Miao Xi's set is supposed to have been revised from, or based on, a Han song from the series known as "Songs for Drum, Fife, and the Nao Bell" (Guchui naoge 鼓 吹鐃歌), supposedly military music. A short note is appended, presumably by the historian Shen Yue 沈約 (443-513), under each song title in Miao Xi's series to identify the Han song it supposedly replaces and to explain the current song's historical referent. ${ }^{74}$ For instance, the note under the title of the third song states: "The third song of the Han series is 'Ai ru zhang'; the third of the current song set, 'Capturing Lü Bu,' describes Lord Cao besieging Linhuai in the east and capturing Lü Bu alive” 漢第三曲艾如張, 今第三曲獲吕布, 言曹公東圍臨淮、 生擒呂布也. ${ }^{75}$ Miao Xi's song set was composed during Emperor Ming's reign. He might

70. Jin shu 39.1143.

71. Wei Zhao describes this work in a memorial to Sun Hao. See Sanguo zhi 65.1462-63.

72. Liang shu 梁書 (Beijing: Zhonghua shuju, 1973), 54.783. Sui shu records a title Funan yiwu zhi 扶南異物 志 by Zhu Ying (33.984).

73. This fascination with geography and locale was the background against which Lu Ji wrote his Account of Luoyang (Luoyang ji 洛陽記), one of the earliest accounts devoted to this famous city. See a discussion of this account in Tian, "Fan Writing," 47-48.

74. The Han series of eighteen songs is also recorded in Shen Yue's "Monograph on Music" (Yue zhi 樂志) in the Song History (Song shu 宋書). The lyrics are often unintelligible and Shen Yue did not even try to punctuate. Although they are believed to be from the Han, this is impossible to ascertain.

75. Song shu (Beijing: Zhonghua shuju, 1974), 22.644. 
have composed them in the Taihe 太和 era (227-33), since the last song is entitled "Great Peace" and begins with the lines, "In the first year of the Taihe era, / the august emperor ascended the throne” 惟太和元年, 皇帝踐祚. ${ }^{76}$

While the "Han" songs for drum and fife as recorded in Song shu apparently have little to do with dynastic concerns, Miao Xi's songs constitute a striking versified narrative of Wei's history. The first song, entitled “Inaugural Pacification" (Chu zhi ping 初之平), gives a sweeping picture of the decline of the Eastern Han, the chaos of the realm, and Cao Cao's meteoric rise to military power soon after the Bian/Han Rebellion in the northwest. ${ }^{77}$ It does so in thirty-three-syllable lines and at a dynamic, vigorous rhythm.

The second song, “Battle at Xingyang” (Zhan Xingyang 戰滎陽), relates Cao's disastrous confrontation with the warlord Dong Zhuo's general Xu Rong 徐榮. At the time the allied army against Dong Zhuo was too fearful to advance; Cao Cao was the only one who led an attack, which resulted in a setback. Cao Cao's horse was wounded and he himself injured by a stray arrow. In a brilliant move, Miao Xi chooses to represent, of all the battles Cao Cao had won in his illustrious military career, one in which he suffered a spectacular defeat. This, however, only serves to accentuate Cao's courage, determination, and devotion to the righteous cause. Evoking the heroic and tragic aura of the "Kingdom's Dead" (Guoshang 國 殤) from the Nine Songs (Jiuge 九歌) in the Lyrics of Chu, the song contains some of the most memorable lines in Chinese poetry, and served as an inspiration for the Tang poet Li $\mathrm{He}$ 李賀 (790-816) in writing his baroque ballads of historical romance.

$\begin{array}{ll}\text { 戰滎陽 } & \text { Fighting at Xingying, } \\ \text { 汴水陂 } & \text { On the dyke of the Bian River. } \\ \text { 戎士憤怒 } & \text { Warriors were wrathful, } \\ \text { 貫甲馳 } & \text { Galloping in full armor. } \\ \text { 陳未成 } & \text { Before the battle line was formed, } \\ \text { 退徐榮 } & \text { We withdrew from Xu Rong. } \\ \text { 二萬騎 } & \text { Their twenty thousand riders } \\ \text { 斬壘平 } & \text { Flattened the camps. } \\ \text { 戎馬傷 } & \text { His war mount was wounded, } \\ \text { 六軍驚 } & \text { The Six Armies alarmed. } \\ \text { 勢不集 } & \text { His might did not prevail; } \\ \text { 眾幾傾 } & \text { Our forces were almost done for. } \\ \text { 白日沒 } & \text { The white sun was sinking; } \\ \text { 時晦冥 } & \text { The hours were dark. } \\ \text { 顧中牟 } & \text { With a backward look at Zhongmou, } \\ \text { 心屏營 } & \text { His heart was troubled. }{ }^{78} \\ \text { 同盟疑 } & \text { The allies were apprehensive, } \\ \text { 計無成 } & \text { Their plan came to naught. } \\ \text { 賴我武皇 } & \text { But thanks to our Martial Sovereign, } \\ \text { 萬國寧 } & \text { Ten thousand states were at peace. }\end{array}$

76. Ibid., 22.647.

77. Cao Cao was living in retirement at his hometown when the rebellion broke out and he was summoned back to the capital to be a military commander. Shortly after the warlord Dong Zhuo 董卓 (d. 192) deposed the young emperor and poisoned the Empress Dowager. Cao Cao fled from the capital and went back home to raise an army, joining the alliance with Yuan Shao along with other nobles resisting Dong Zhuo. Sanguo zhi 1.5-6.

78. Earlier, when Cao Cao fled from the capital controlled by Dong Zhuo, he had passed through Zhongmou and was arrested; he was only released due to the intervention of a wise county clerk. 
While the facts cited in the song - the wounding of the war mount, the twenty thousand riders commanded by Xu Rong-correspond to or supplement Cao Cao's biography in dynastic history, it is the dramatized imagery of the sun sinking on the battlefield and the momentary uncertainty in the hours of darkness that truly brings the scene alive. This sort of imaginary detail, physical and psychological, is exactly what gives the Tang poet Li He's historical ballads so much theatrical vividness and emotional force.

The next seven songs are "Apprehending Lü Bu," “Victory at Guandu” (Ke Guandu 克 官渡), “Native Land” (Jiu bang 舊邦), “Martial Deeds Accomplished” (Ding wugong 定武 功), “Taking Willow City” (Tu Liucheng 屠柳城), “Vanquishing Southern Jing” (Ping nan Jing 平南荊), and "Pacifying the Land within the Pass" (Ping Guanzhong 平關中). They relate, as the titles indicate, a series of conquests by which Cao Cao gradually consolidated his rule over north China. The fifth song, "Native Land," stands out as the only song written in the four-three-syllable meter throughout. Instead of depicting another military campaign, it describes Cao Cao's compassion for his people, the key characteristic of a good ruler.

In 202, after his grand victory over one of his most powerful enemies, Yuan Shao 袁紹 (d. 202), Cao Cao returned to Qiao 譙 (in modern Anhui), his hometown, sought out the kin of those who had died in the civil war without sons, and established heirs for them. He also ordered a temple erected to make sacrifices to their souls. Cao Cao had issued an instruction at the time, and the song adheres closely to that text. The instruction reads:

I raised the righteous troops to purge the world of violence and disorder; and yet, so many of the people of my native land have died that I now walk in the city all day long without seeing anyone I used to know-this saddens and wounds my heart. I hereby command that, for all commanders and soldiers who have died without sons since the raising of the righteous troops, let their kith and kin be sought out to be their heirs; let the heirs be given farming land, and be provided with oxen to plow the field, by the government, and let there be a school and teachers to educate them; let a temple be erected on behalf of the survivors so that they can make sacrifices to their forefathers. If the soul does have consciousness after death, then what regret would I have after a hundred years [i.e., after my death] ?79 $^{79}$

吾起義兵, 為天下除暴亂, 舊土人民死喪略盡, 國中終日行, 不見所識, 使吾悽愴傷懷. 其舉 義兵已來, 將士絕無後者, 求其親戚以後之, 授土田, 官給耕牛, 置學師以教之. 為存者立廟, 使祀其先人. 魂而有靈, 吾百年之後何恨哉

Miao Xie's song is as follows:

舊邦蕭條
心傷悲
孤魂翩翩
當何依
游士戀故
涕如摧
兵起事大
令願違
博求親戚
在者誰
立廟置後
魂來歸

The native land is desolate: the heart grieves.

Lonely souls drift on: where would they settle?

This traveler longs for his old friends, tears fall in pain;

Troops are raised, the enterprise is weighty, causing my wish to go astray.

Widely I seek the kith and kin: who are the survivors?

Let a temple be erected, let heirs be appointed, let the souls come home. 
In Cao Cao's instruction, the concerns for the war dead are intertwined with a moving anticipation of his own death. The erection of a temple is more for the living than for the dead (the clause wei cunzhe li miao 為存者立廟 literally means "erecting a temple for the survivors," and there is also the skeptical remark, "If the soul does have consciousness after death"); nevertheless, Cao imagines that his own soul would take comfort in the knowledge that he had done his best to commemorate the fallen. In Miao Xi's song, the voice could easily be Cao Cao's, now immortalized and endlessly publically repeatable in ritual verse, speaking in the first person to the audience. It is a song about remembering Cao Cao, himself now dead, remembering the dead. Its last line, reenacted as it is in a ritual ceremony, could be heard as calling the souls of the kingdom's dead as well as that of Cao Cao himself. Its insertion in the middle point of the nine songs about the conquests of Cao Cao, posthumously called the "Martial Emperor," thus takes on a symbolic significance underlying the entire song series.

The tenth song in the series, "Responding to the Imperial Destiny" (Ying di qi 應帝期), is an ode to Cao Pi's founding of the Wei dynasty and thus represents a change of tempo. While the previous songs are all about the Martial Emperor's military campaigns, this song presents a picture of the peace and prosperity of the empire, with auspicious omens abounding. It places a particular emphasis on the civilizing rule and cultural accomplishments of Cao Pi, hailed by his posthumous title "the Cultured Emperor" (Wenhuang 文皇) at the beginning of the song.

The eleventh song, "Harmony and Prosperity" (Yongxi 魯熙), continues the eulogy of the Wei governance. It stresses the accord shared by the ruler and ministers, and sings selfreflexively of the harmonious and harmonizing power of music. The phrasing of the following stanza, marked by the use of a new rhyme, evokes many of the public banquet poems written by poets in Cao Cao and Cao Pi's entourage, with the mention of ale and music. ${ }^{80}$

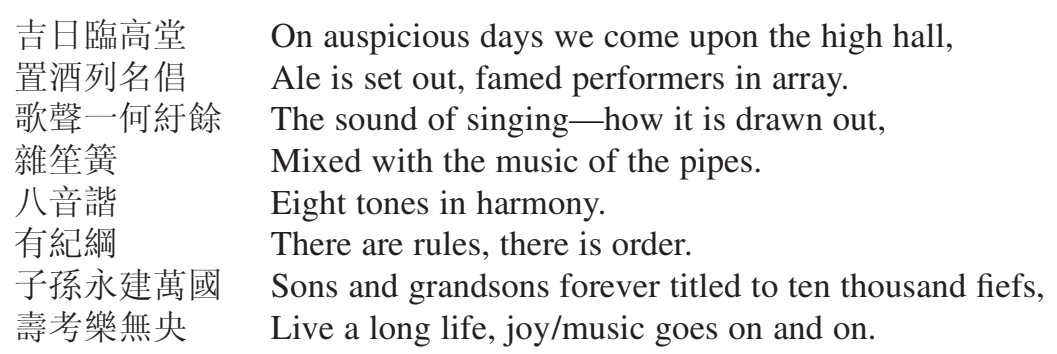

The harmony of the eight tones of music is festive but also imposes a sense of order (you jigang 有紀綱), a phrase that echoes and effectively counters the "loss of rules and order" (wu jijing 無紀經) lamented in the first song. The homily to the state of Wei culminates in the last song of Miao Xi's series, "Great Peace," a panegyric on the current ruler, Emperor Ming.

If the Wei songs for drum and fife are versified history performed in a court ritual context, perhaps to the accompaniment of dance and mime as well, we must remember that rituals serve to promote cohesion and collaboration among the ritual's participants and to join individuals in common identity-building, which is vital to any group's survival. Music plays a crucial role in such rituals, as it does in inspiring and maintaining a sense of solidarity. The effect of music is intensified when the words set to the music construct history and shape social memory by performing, repeating, and solidifying a careful selection of certain historical events. The Wei songs for drum and fife constitute a dynasty-founding epic, a

80. For the template verbal sequence of a "food and ale" couplet followed by a couplet on music in early thirdcentury poetry, see Owen, The Making of Early Chinese Classical Poetry, 208-10. 
close-knit set of temporally progressing songs chronicling Wei's history. While the Shij ing also has many poems eulogizing Zhou's forefathers and Zhou's founding, the poems are not organized in such a systematic manner-they do not form a set and perhaps had not been intended to be performed as a set as these Wei songs are. This is thus a unique set of songpoems, and it was to be emulated subsequently by each dynasty after the Wei.

Emulation took place synchronically, for we have a similar set of songs from $\mathrm{Wu}$, composed by none other than Wu's court-appointed historian Wei Zhao. The Eastern Jin scholar He Chengtian 何承天 (370-447) is quoted in Shen Yue's "Monograph on Music" as saying, "People all say that the Wu court did not have elegant "high music"” 世咸傳吳朝無雅樂. ${ }^{81}$ Shen Yue, however, does not agree with this claim, and cites the following remark from Wei Zhao's memorial to the throne presenting his songs for drum and fife: "These [songs] should be given to those in the Music Office who are skilled in singing to be sung and practiced" 當付樂官善哥者習哥. Shen argues that this shows “there must have been Music Officers in the Wu court, and those who were good at singing were able to sing the lyrics to the accompaniment of strings and pipes” 然則吳朝非無樂官, 善哥者乃能以哥辭被絲管. According to Shen Yue, Wei Zhao had presented the songs to Sun Xiu 孫休, Wu's third ruler, Emperor Jing 景帝 (r. 258-264). If Shen Yue's information is correct, then Wei Zhao's songs were composed long after Miao Xi's.

Indeed, in more than one way these songs must be heard or read against the Wei songs: on the one hand, they were composed as an ideological contestation of Wei's claim to legitimacy and provided a different perspective on history; on the other hand, there are many echoes of the Wei songs in terms of phrasing and imagery, consciously or unconsciously. The meter employed in these songs is another intriguing element in configuring the relation of the two song sets. According to the explanatory notes in Shen Yue's "Monograph on Music," Wei Zhao's songs follow exactly the same sequence as Miao Xi's songs in "transforming" the existing Han "Songs for Drum, Fife, and Nao Bell." Yet, while some of Wei's songs are written in the same meter (for example, the first Wu song has thirty three-syllable lines just like the first Wei song), this does not apply to all of the songs. For instance, the sixth Wu song, “Capturing Wan City" (Ke Wancheng 克皖城), though considered by Shen Yue as the “equivalent” of the sixth Han song, "Fighting South of the Wall” (Zhan cheng nan 戰城南), is metrically identical with the fifth Wei song, "Native Land," which is in turn the equivalent of the fifth Han songs "Wengli" 翁離. That is, both Wu song No. 6 and Wei song No. 5 share the distinctive use of six four-three-syllable lines.

Presumably, the meters of the lyrics have a close relationship to music. Did Wu use the same music for the songs as Wei did? Or, perhaps more likely, did Wu invent its own music but try to maintain to some extent the illusion of "Han roots"?

Shen Yue's note for the first Wu song states:

"The Impairment of the Fiery Essence" describes the decline of the Han house and Emperor Wulie's [i.e., Sun Jian] manly aspiration to come to the rescue, yet [in his efforts to aid the Han] his kingly enterprise itself began. Han songs have a "Vermillion Egret," and this piece is its equivalent. This is the first song.

炎精缺者, 言漢室衰, 武烈皇帝奮迅猛志, 念在匡救, 然而王迹始乎此也。漢曲有朱 鷺, 此篇當之。第一。

The use of these imperial designations for Wu rulers- "Emperor Wulie" for Sun Jian and later “August Emperor” (Dahuangdi 大皇帝, Sun Quan's posthumous title) for Sun Quan- 
seems to suggest that Shen Yue had directly copied the words from original Wu documents, perhaps even from Wei Zhao's memorial presenting the songs to the throne.

Like "Inaugural Pacification," Wei Zhao's first song also begins its historical narrative in the early 180s. It was a time of disorder in the Han empire that marks the rise of the three men who were to found the Three Kingdoms respectively. While Han's decline, signified by the "impairment of the fiery essence," is duly depicted, the narrative focus of the Wu song is naturally on Sun Jian, who had, much like Cao Cao, initiated Wu's "kingly enterprise." Yet, whereas the first nine Wei songs all focus on Cao Cao, only two Wu songs, i.e., the first and second, “Han's Twilight" (Han zhi ji 漢之季), are devoted to Sun Jian. Noticeably, and also understandably, the Wu song series entirely bypasses Sun Quan's elder brother Sun Ce, who was Sun Jian's oldest son and had played a crucial role in the founding of Wu. The third through the ninth songs were all dedicated to the narration of Sun Quan's accomplishments.

The tenth Wu song, "Following the Heavenly Order" (Cong lishu 從歷數), is an ode to the founding of the dynasty, just as the tenth song in the Wei series sings of Wei's founding. The opening of this song, "Following the heavenly order: / O how magnificent is our emperor" 從歷數, 於穆我皇帝, is closely patterned on that of the tenth Wei song, "Responding to the imperial destiny, / O how brightly manifested, our Emperor Wen” 應帝期, 於 昭我文皇. ${ }^{82}$ The eleventh and twelfth Wu songs, “Receiving Heavenly Mandate" (Cheng tianming 承天命) and "Sagely Transformation" (Xuanhua 玄化), appear to be eulogies of the current emperor Sun Xiu, as the explanatory notes refer to the ruler as simply "Shang”上 (the Exalted) rather than as "August Emperor" as in previous notes. Or one could also easily take them to be a general praise of the Wu rule, much in the same vein as the last Wei songs.

The last $\mathrm{Wu}$ song, however, contains a sentiment missing in the final Wei songs:

\begin{tabular}{|c|c|}
\hline 化象以天 & The sagely transformation is modeled on heaven; \\
\hline 长下聖真 & His Majesty embodies the sagacious truth. \\
\hline 皇綱 & He opens wide the imperial net of rules and laws, \\
\hline & Following the Way and bringing peace to his people. \\
\hline 而雲布 & His benevolent grace spreads widely like clouds. \\
\hline 下崚腤 & ove and those below are harmonious with their kith \\
\hline & Ruler and ministers enjoy the high music \\
\hline & narvelous and new. \\
\hline & We promote culture, and perfect military strategies in court, \\
\hline & the imperial carriage will be readied to inspect the Luo \\
\hline & \\
\hline & O how peaceful and serene! \\
\hline & With the four seas all are joyful. \\
\hline & Thereupon He equals the Three Emperors and Five Kings. \\
\hline
\end{tabular}

In lines 7-10, the motif of ruler and ministers sharing the joy of music is consistent with the Wei song "Harmony and Prosperity," but the proclamation of strategizing and "inspecting the Luo River," in other words capturing Wei's capital Luoyang, is explicitly military and militant.

82. The opening lines of both Wei and Wu songs echo Shi jing poems praising King Wen, the founder of the Zhou. The Wu opening is based on "The Ancestral Temple" (Qing miao 清廟): “The Way of Heaven / O magnificently goes on and on” 維天之命, 於穆不已 (Maoshi zhushu 19.708); the Wei opening is based on "King Wen" (Wen wang): “King Wen is on high, / O how brightly manifested to Heaven” 文王在上, 於昭于天 (Maoshi zhushu 16.533). 
Just as the structural organization of the Wu series mirrors the Wei series, the contents of individual $\mathrm{Wu}$ songs also present interesting similarities with variations. Take for instance the third song, "Expanding the Martial Forces" (Shu wushi 攄武師):

$\begin{array}{ll}\text { 攄武師 } & \text { He expanded the martial forces, } \\ \text { 斬黃祖 } & \text { He executed Huang Zu. }{ }^{83} \\ \text { 肅夷凶族 } & \text { He destroyed the wicked tribes, } \\ \text { 革平西夏 } & \text { And transformed and pacified the Western Xia. }{ }^{84} \\ \text { 炎炎大烈 } & \text { O fiery were his great flames } \\ \text { 震天下 } & \text { That awed all under heaven. }\end{array}$

We may compare it with the third Wei song, "Capturing Lü Bu":

$\begin{array}{ll}\text { 獲吕布 } & \text { He captured Lü Bu, } \\ \text { 翏陳宮 } & \text { And slayed Chen Gong. } \\ \text { 芝夷鯨鯢 } & \text { He destroyed the whales, } \\ \text { 驅駎犨雄 } & \text { He drove the heroes. } \\ \text { 囊括天下 } & \text { He put all under heaven in a bag, } \\ \text { 運掌中 } & \text { Manipulating it in his palm. }\end{array}$

The number of lines and the meter are identical; both opening couplets state the execution of an arch-enemy. The third line of the Wu song repeats the verb yi 夷, to cut down and destroy, in the third line of the Wei song. The third couplet reiterates the idea of the third couplet of the Wei song, again with the repetition of a phrase, tianxia 天下 (all under heaven).

The $\mathrm{Wu}$ songs provide a southern perspective to the same historical events portrayed in the Wei songs. In terms of timeline, the fourth Wu song, "Battle of Black Woods" (Fa Wulin 伐烏林), corresponds to the eighth Wei song, "Vanquishing Southern Jing," which is about Cao Cao's capture of Jingzhou in 208. The Wei song understandably chooses to focus on Jingzhou's surrender and Cao Cao's military might ("Between the vast Yangzi and Han rivers, / All became the Great Wei's subjects” 陶陶江漢間, 普為大魏臣), without mention of Cao's subsequent defeat at Black Woods or the later loss of Jingzhou. In contrast, the Wu song represents the events of the same year but chooses to commemorate the famous battle, known as the Battle of Red Cliff (Chibi zhi zhan 赤壁之戰), in which the Sun-Liu allies soundly defeated Cao Cao's army.

$\begin{array}{ll}\text { 曹操北伐 } & \text { Cao Cao went on a northern campaign } \\ \text { 拔柳城 } & \text { And captured Willow City. } \\ \text { 乘勝席卷 } & \text { Taking advantage of his victory, like rolling a mat, } \\ \text { 遂南征 } & \text { He then came to the south. } \\ \text { 劉氏不睦 } & \text { The Lius did not get along; } \\ \text { 八都震驚 } & \text { The eight principalities were taken by surprise. }{ }^{85} \\ \text { 眾既降 } & \text { After their surrender, } \\ \text { 操屠荊 } & \text { Cao slaughtered Jingzhou. } \\ \text { 舟車十萬 } & \text { With ten thousand navy and cavalry, }\end{array}$

83. This refers to Sun Quan's defeat of the general Huang Zu in 208, who had been responsible for Sun Jian's death.

84. The "Western Xia" refers here to the region of Jingzhou and Xiangyang 襄陽 (in modern Hubei).

85. Liu Biao 劉表 (142-208), governor of Jingzhou, was alienated from his eldest son borne by his ex-wife and chose his younger son, borne by his second wife, as heir. This created a rift in the Liu family. Jingzhou had eight commanderies. 


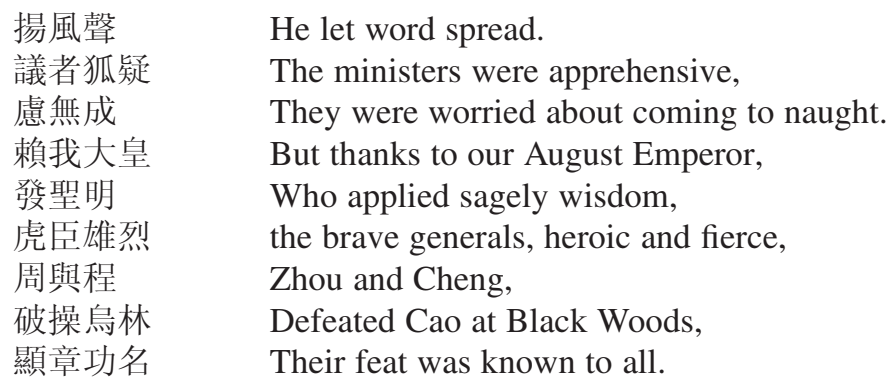

Cao Cao's capture of Willow City and the surrender of Jingzhou are depicted succinctly in the first few lines, in a tenor much different from the seventh and eighth Wei songs devoted to these two deeds. While the eighth Wei song states that Cao Cao "pacified its [Jingzhou's] people" 撫其民, the Wu song claims that he "slaughtered" or "destroyed" the prefectural capital. There is no mention of Wu's ally Liu Bei 劉備 (161-223) in the victory, which is entirely attributed to Sun Quan's decisiveness, and to the Wu generals Zhou Yu 周瑜 (175-210) and Cheng Pu 程普. Yet, lines 11-14 bear a remarkable similarity to the lines from the second Wei song:

$\begin{array}{ll}\text { 同盟疑 } & \text { The allies were apprehensive, } \\ \text { 計無成 } & \text { Their plan came to naught. } \\ \text { 賴我武皇 } & \text { But thanks to our Martial Sovereign, } \\ \text { 萬國寧 } & \text { Ten thousand states were at peace. }\end{array}$

Metrically, the fifth Wu song entitled "Autumn Wind" (Qiufeng 秋風) is noteworthy because it is composed largely in a five-syllable-line meter, singing of defending the frontier from a soldier's point of view:

$\begin{array}{ll}\text { 秋風揚沙鹿 } & \text { Autumn wind blows up sand and dust, } \\ \text { 寒露霍衣裳 } & \text { Cold dews soak the clothes. } \\ \text { 角弓持弦急 } & \text { Horned bows with tightened strings: } \\ \text { 鳩鳥化為鷹 } & \text { The cuckoo transforms into a falcon. }{ }^{86} \\ \text { 邊垂飛羽檄 } & \text { From the frontier flies a feathered message. } \\ \text { 寇賊侵界疆 } & \text { The bandits invade our frontiers. } \\ \text { 跨馬披介甹 } & \text { I get on my mount, wearing full armor, } \\ \text { 慷慨懷悲傷 } & \text { My heart is impassioned, filled with sorrow. } \\ \text { 辭親向長路 } & \text { Bidding my family farewell, I head on the long road, } \\ \text { 安知存與亡 } & \text { How do I know whether I will live or die! } \\ \text { 窮達固有分 } & \text { Destitute or ennobled, each man has a destiny, } \\ \text { 志士思立功 } & \text { A man with aspirations longs to distinguish himself, } \\ \text { 邀之戰場 } & \text { He is bidden to join the battlefield. } \\ \text { 身逸獲高賞 } & \text { Surviving, I will reap a great reward; } \\ \text { 身沒有遺封 } & \text { Gone, I will be granted title and fief after death. }\end{array}$

The explanatory note to this poem states the significance of the poem: "Autumn Wind' shows that the August Emperor deployed his people with respect, and the people forgot [the fear of] death” 秋風者, 言大皇帝說以使民, 民忘其死. ${ }^{87}$ One could see the similarity

86. According to Zheng Xuan's commentary on Zhou li, the cuckoo is transformed into a falcon in the eighth month (the first month of autumn). Zhou li zhushu 7.107.

87. Song shu 22.657. 
between a song like this and some of the "macho ballads" written by the Wei poet Cao Zhi, such as his famous "Ballad of the White Horse" (Baima pian 白馬篇); and in many ways this poem prefigures the sort of frontier ballads written by the fifth-century poet Bao Zhao 鮑照 (414-466), the "initiator" of the subgenre of "frontier poetry." Nevertheless, in a state ritual song, the use of the perspective of a warrior with no obvious class marker is an ingenious move, giving an extraordinary sense of purpose and dignity to all common soldiers.

The seventh Wu song is a denunciation of Guan Yu 關羽 (d. 220), the Shu-Han general who would, of all Three Kingdoms heroes, experience the ultimate apotheosis in the later tradition and be worshipped throughout Southeast and East Asia as a god of righteousness. $\mathrm{He}$ is not, however, represented in a favorable light in the song entitled "Guan Betrayed Virtue" (Guan beide 關背德):

\begin{tabular}{|c|c|}
\hline 關背德 & Guan betrayed virtue, \\
\hline 作鴟張 & Spreading his wings like a hooting owl. \\
\hline 割我邑城 & He took our county, \\
\hline 圖不祥 & Hatching evil plans. \\
\hline 稱兵北伐 & Raising troops he led a northern attack, \\
\hline 圍㚞襄陽 & Laying siege to Fan and Xiangyang. \\
\hline 咩臂大於股 & Alas, "the arm becomes bigger than the thigh," \\
\hline 受其殊 & The body would certainly suffer. \\
\hline 嵬巍吳聖主 & $\mathrm{O}$ grand is Wu's sagely ruler \\
\hline 㕡德與玄通 & Whose holy virtue is connected to Heaven. \\
\hline 县玄通 & Connected to Heaven, \\
\hline 呂蒙 & He trusted and deployed Lü Meng, \\
\hline 洪汇池 & Who led a fleet over the vast moat \\
\hline 長江 & And sailed upriver on the Yangzi. \\
\hline 一何桓桓 & How extraordinary is his divine martial prowess, \\
\hline 上與風翔 & His renown soars with wind. \\
\hline 工安城 & He pacified Jiangling and Gong'an one by one, ${ }^{88}$ \\
\hline 阝邦 & And occupied the land of Ying. \\
\hline & The Bandit Yu yielded his head, \\
\hline & A hundred barbarian tribes all submitted. \\
\hline 比隆 & O glorious! Wu's majesty is peerless. \\
\hline
\end{tabular}

The Qing poet Wang Shizhen's 王士禛 (1634-1711) moral sentiments were so offended by this song that he called it "the barking of a mad dog," which he claimed had caused his hair to “all rise up [with anger]” 狺狺狂吠, 讀之髮指. ${ }^{89} \mathrm{He}$ also condemned Miao Xi's, Wei Zhao's, and the later Western Jin "Songs for Drum and Fife" composed by Fu Xuan as all “shallow, vulgar, with no more ancient aura” 淺俗無復古意 and “filled with senseless and insubordinate talk” 其詞尤多狂誖. Wang's comment serves to best demonstrate ideological changes over time.

88. The editorial note to Song shu suggests emending “Jiang An cheng”江安城 to “Gong'an cheng” 公安城, because "there was no Jiang'an during the Jian'an era." Song shu 22.658. I believe that "Jiang An" is an abbreviation of "Jiangling and Gong'an" due to line length constraint, because the adverb $l i$ 歷 in lifu 歷撫 has the meaning of "one by one" and also because there are several references in the dynastic history to Sun Quan's army "marching westward and attacking Gong'an and Jiangling”引兵西襲公安江陵. Sanguo zhi 14.451, 14.440.

89. Gufuyuting zalu 古夫于亭雜錄 (Beijing: Zhonghua shuju, 1988), 3.164. 
Interestingly, "Guan Betrayed Virtue" again contains verbal echoes of the Wei song in the corresponding position in the sequence, "Taking Willow City," which lauds Cao Cao's victory over the Wuhuan 烏桓 people in 207:

屠柳城
功誠難
越度隴塞
路漫漫
北踰岡平
但聞悲風正酸
蹋頓授首
遂登白狼山
神武熱海外
永無北顧患

Taking Willow City:

The mission was truly hard.

Crossing the Dragon Pass: ${ }^{90}$

The road stretched endlessly.

To the north traversing Flat Peaks,

One only heard the wail of the bitter wind.

Tadun yielded his head,

And he ascended the White Wolf Mountain.

His divine martial prowess inspired awe beyond the seas,

There shall be no worry about looking back at the north.

We notice that phrases like “divine martial prowess" 神武 and “yield his head”授首 appear in the $\mathrm{Wu}$ song as well, and that the wailing wind in the Wei song becomes the soaring wind that carries Sun Quan's fame far and wide in line 16 of the Wu song.

Finally, the eighth Wu song entitled “Opening up Jing's Gate” (Tong Jingmen 通荊門) and the ninth entitled “Demonstrating Vast Virtue" (Zhang hongde 章洪德) deliberately offset the Wei songs that are in the corresponding positions in the sequence. If the eighth Wei song describes Jingzhou's surrender to Cao Cao, then the Wu song narrates Wu and Shu's conflicts and their renewal of alliance in 222, with "Jing's Gate" referring to a strategic pass in Jingzhou between Wu and Shu. In the Wei sequence, the ninth song narrates Cao Cao's conquest of the northwest; the Wu equivalent, on the other hand, describes Wu's colonial exploration to the far south.

\section{CONCLUSION: REMAKING HISTORY}

Wei and $\mathrm{Wu}$, as we have seen, both engaged in multi-media state-building and ideological warfare. They endeavored to shape public memory and establish dynastic legitimacy through the writing of history and through repeated public musical performance of versified history. Those ritual songs about dynasty founding were to be emulated through the ages in premodern China. Indeed, even the People's Republic of China has its very own set in the grand "music and dance epic" known as "East Is Red," which dramatizes the history of the modern Chinese revolution and of the Communist Party under the leadership of Chairman Mao Zedong.

The remaking of history in the title of this article refers not only to Wei's and Wu's history projects but also to the attempt to recast the conventional mold of Chinese literary history based on the deep-rooted "northern/Wei-Jin" political orthodoxy. Reflections on the literary production of Shu and Wu enable a more comprehensive picture of the cultural dynamics of the Three Kingdoms period well known for military strife. The Wu ritual songs (and, for that matter, the Wei songs as well) should receive much more consideration in Chinese literary

90. Longsai 隴塞 usually refers to the northwestern frontiers in modern-day Shanxi and Gansu; here it should probably be emended to Longsai 龍塞, a reference to Black Dragon Pass (Lulongsai 盧龍塞) in modern-day Hebei. According to Cao Cao's biography, he "led the army out of the Lulong Pass . . . went through Baitan, traversed the Flat Peaks, arrived at the Xianbei territories, and headed eastward toward Willow City [in modern-day Liaoning] ... In the eighth month, he ascended the White Wolf Mountain . . . slayed Tadun [the Wuhuan khan]” 引軍出盧龍 塞 ... 經白檀, 歷平岡, 涉鮮卑庭, 東指柳城... 八月, 登白狼山 . . 斬蹋頓. Sanguo zhi 1.29. 
history than they do now. On the one hand, these songs had provided models for historical ballads in the later poetic tradition; on the other hand, as part of the state's cultural work, they fulfilled an important contemporary political function, exemplifying the $\mathrm{Wu}$ general and nobleman Lu Jing's 陸景 (249-280) remark in his book, Normative Words (Dianyu 典語):

What is called wen is not just holding scrolls at the door of a Confucian scholar or demonstrating the comprehensiveness of brush and ink; what we prize in wen are the profundity and magnificence of its creative and transformative power and the magnificence of ritual and music. ${ }^{91}$ 所謂文者, 非徒執卷於儒生之門, 攄筆於翰墨之悉, 乃貴其造化之淵禮樂之盛也.

In this article I have shown that Wei Zhao might very well have been inspired by, and consciously based his songs on, Miao Xi's set. Throughout the Wu songs there are verbal echoes of the corresponding Wei songs in the sequence. The $\mathrm{Wu}$ songs resonate with, and yet contest and offset, the northern perspective of the Wei court, and in this context the resonance seems to be a deliberate rhetorical strategy that serves to more effectively highlight the differences between the two series. Lu Jing's younger brother Lu Ji was clearly in agreement with Lu Jing's conception of wen: ten years after Jin's conquest of $\mathrm{Wu}$, he left $\mathrm{Wu}$ for Luoyang; there, embodying the "creative and transformative power" of wen, he would pay particular heed to the northern music and rewrite it in a manner reminiscent of Wei Zhao's making of the songs for drum and fife.

Ultimately this article implicitly asks the question how to write literary history when there is only scant material from the period under question. Are we to dismiss such a period out of hand, or are we to perform textual excavations and make use of what we have to try and reconstruct, as best as we can, what once was, even knowing that it can only be a partial picture? The right answer seems to me the latter. Perhaps more important, a good literary history of the Chinese medieval period (here referring to the period roughly from the first through the tenth century), which is the age of manuscript culture and that of heavy textual losses and transfigurations, should be written with the awareness of the incomplete and imperfect nature of the data we do have. Such a history should consider the phenomenon of textual losses and transfigurations as well as incorporate reflection on the underlying reasons in its critical inquiry.

91. Taiping yulan 585.2766. Yan Kejun cites the passage with cai 采 (splendor) for $x i$ 悉 and a slight variation of the word order of the last clause. Quan sanguo wen 70.1433. 
